\title{
Geologic Map of the Central Beaverhead Mountains, Lemhi County, Idaho, and Beaverhead County, Montana
}
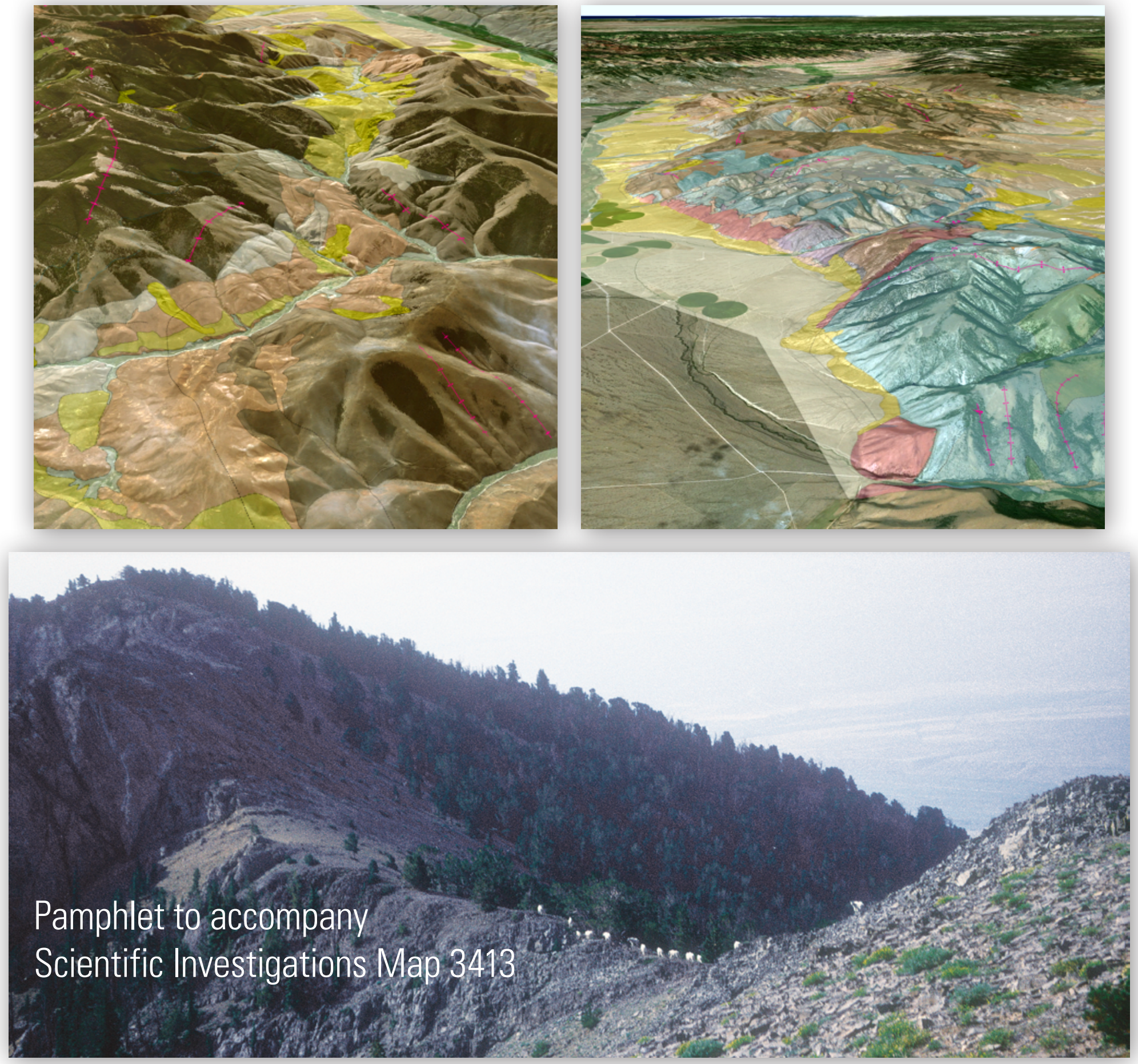

U.S. Department of the Interior U.S. Geological Survey 
Cover. Top left-Three-dimensional draped image showing the east-directed Cow Creek thrust fault, Lower Cow Creek-Agency Creek tear fault segment, and folds associated with the thrust fault, as well as the normal-fault system that overprinted the compressional structures, defined the Ramsay Mountain ridge and formed the Yearian-Cow-Agency basin(s) into which Cenozoic volcanic and sedimentary rocks were deposited. See figure 3 for geologic features. View looks south across Agency Creek and up the Cow Creek drainage. Geologic polygons, fold axes, and fault lines are draped over the shaded relief map. Image by Stuart A. Giles.

Top right-Three-dimensional draped image of the map area, looking north. Image by Stuart A. Giles.

Botttom-Photograph of angular unconformity between Mesoproterozoic Gunsight Formation and overlying Mississippian Middle Canyon and Scott Peak Formations. View looks southwest from Goat Mountain toward lower Little Eightmile Creek. Mountain goats are along the ridgeline, above the unconformity. Photograph by K. Lund. 


\section{Geologic Map of the Central Beaverhead Mountains, Lemhi County, Idaho, and Beaverhead County, Montana}

By Karen Lund

Pamphlet to accompany

Scientific Investigations Map 3413 


\title{
U.S. Department of the Interior \\ RYAN K. ZINKE, Secretary
}

\author{
U.S. Geological Survey \\ James F. Reilly II, Director
}

U.S. Geological Survey, Reston, Virginia: 2018

For more information on the USGS - the Federal source for science about the Earth, its natural and living resources, natural hazards, and the environment-visit https://www.usgs.gov or call 1-888-ASK-USGS.

For an overview of USGS information products, including maps, imagery, and publications,

visit https://store.usgs.gov.

Any use of trade, firm, or product names is for descriptive purposes only and does not imply endorsement by the U.S. Government.

Although this information product, for the most part, is in the public domain, it also may contain copyrighted materials as noted in the text. Permission to reproduce copyrighted items must be secured from the copyright owner.

Suggested citation:

Lund, K., 2018, Geologic map of the central Beaverhead Mountains, Lemhi County, Idaho, and Beaverhead County, Montana: U.S. Geological Survey Scientific Investigations Map 3413, pamphlet 27 p., scale 1:50,000, https://doi.org/10.3133/sim3413.

ScienceBase data release GIS and other files that support this report are available at https://doi.org/10.5066/P905PTI4

ISSN 2329-132XX (online) 


\section{Contents}

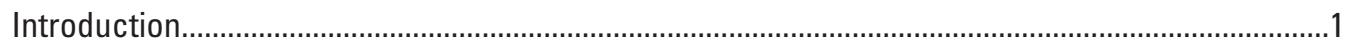

Setting

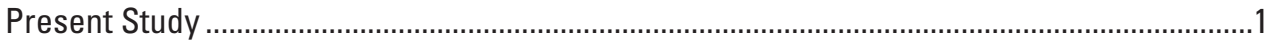

Depositional Settings of Mesoproterozoic and Paleozoic Rocks...................................................

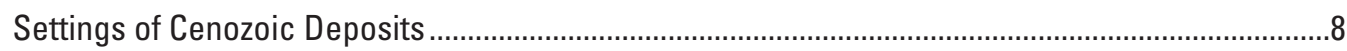

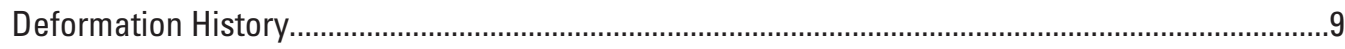

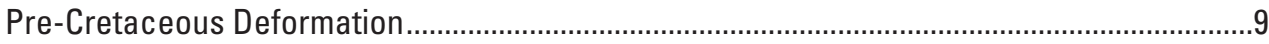

Cretaceous Compressional Structures ..............................................................................

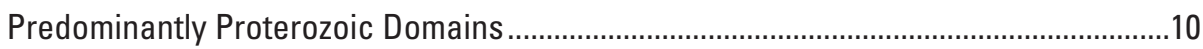

Maiden Peak Domain ........................................................................................

Deadhorse Thrust Fault ..................................................................................10

Shenon Creek Thrust Fault ...............................................................................

Cabin Thrust Plate .............................................................................................

Cow Creek Thrust Plate ........................................................................................10

Southern, Predominantly Paleozoic Domains...................................................................11

Goat Mountain Domain ............................................................................................11

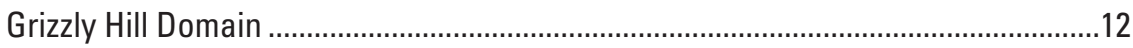

Thompson Gulch Domain ................................................................................13

Baby Joe Gulch Domain ......................................................................................

Thrust-Fault Geometries ............................................................................................

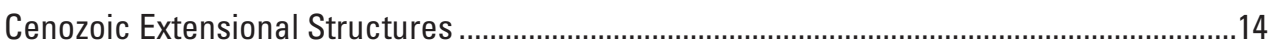

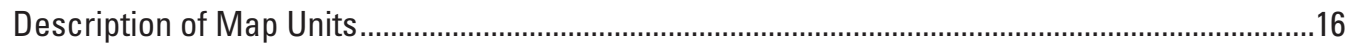

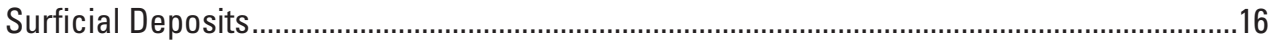

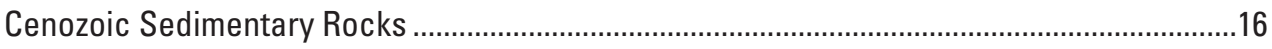

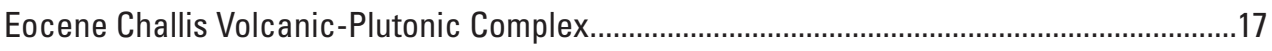

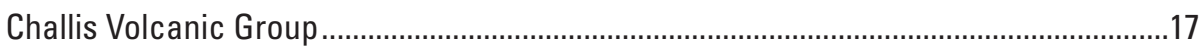

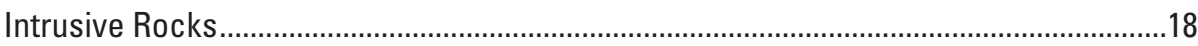

Mesozoic To Neoproterozoic? Sedimentary and Metasedimentary Rocks............................19

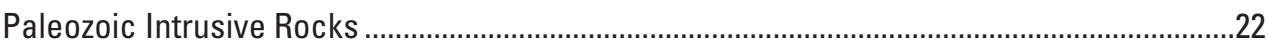

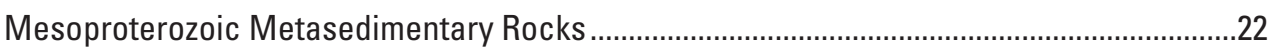

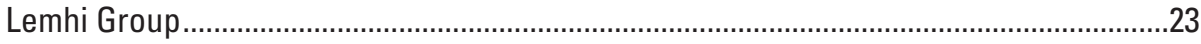

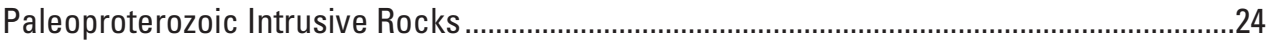

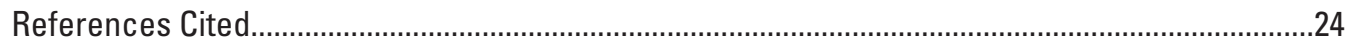

\section{Figures}

1. Index map showing the study area and nearby geographic features.................................

2. Index map showing areas of previous mapping in the study area ....................................

3. Index map showing locations of named structures, structural domains, and

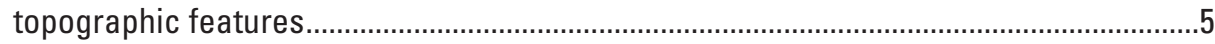

4. Stratigraphic correlation chart for units in individual structural domains and subdomains. 


\section{Conversion Factors}

U.S. customary units to International System of Units

\begin{tabular}{|c|c|c|}
\hline Multiply & By & To obtain \\
\hline \multicolumn{3}{|c|}{ Length } \\
\hline inch (in.) & 2.54 & centimeter $(\mathrm{cm})$ \\
\hline inch (in.) & 25.4 & millimeter (mm) \\
\hline foot $(\mathrm{ft})$ & 0.3048 & meter (m) \\
\hline mile (mi) & 1.609 & kilometer (km) \\
\hline
\end{tabular}

International System of Units to U.S. customary units

\begin{tabular}{lll}
\hline \multicolumn{1}{c}{ Multiply } & By & \multicolumn{1}{c}{ To obtain } \\
\hline & Length & \\
\hline centimeter $(\mathrm{cm})$ & 0.3937 & inch (in.) \\
meter (m) & 3.281 & foot (ft) \\
kilometer (km) & 0.6214 & mile (mi) \\
meter (m) & 1.094 & yard (yd) \\
\hline
\end{tabular}

\section{Datum}

Vertical coordinate information is referenced to the North American Vertical Datum of 1988 (NAVD 88).

Horizontal coordinate information is referenced to the North American Datum of 1983 (NAD 83). 


\title{
Geologic Map of the Central Beaverhead Mountains, Lemhi County, Idaho, and Beaverhead County, Montana
}

\author{
By Karen Lund
}

\section{Introduction}

\section{Setting}

The Beaverhead Mountains (fig. 1) have a uniquely longlived, complex geologic setting. The mountain range includes orthogneiss in the western margin of the Paleoproterozoic and Archean Wyoming craton. This circa (ca.) 2.5 giga-annum (Ga) orthogneiss (Kellogg and others, 2003) intruded metasedimentary rocks of the Montana metasedimentary province (possibly older than $3 \mathrm{Ga}$; M'Gonigle and others, 1991; Mueller and Frost, 2006). After its formation, the basement block was structurally reactivated and uplifted multiple times. In the Mesoproterozoic, ca. 1.4 Ga extension resulted in a basement high on the east, paired with a depositional depression on the west. Debris shed from the basement high was transported westward into a large Mesoproterozoic basin to form the Lemhi Group and related strata; the coastline for this basin is preserved about 10 kilometers (km; 6 miles [mi]) east of the map area (Tysdal and others, 2005) but is structurally disrupted and concealed along the eastern part of the map area. The very thick, fine-grained, nonfossiliferous arkosic strata of the Lemhi Group and overlying units were tilted and eroded prior to deposition of Paleozoic strata.

In the late Neoproterozoic to early Paleozoic, the map area was part of the intracontinental rift zone along the western portion of the paleocontinent Laurentia (the Precambrian core of North America) that was caused by breakup of the supercontinent Rodinia. Both Precambrian basement and Mesoproterozoic Lemhi basin rocks were upthrown in forming the Lemhi arch (Sloss, 1954; Scholten, 1957; "note that Lemhi Arch" was used in those initial publications and in Lund, 2008; Lund and others, 2010), which formed along the rifted shoulder of western Laurentia (Lund, 2008). The Late Cambrian to Early Ordovician syenite pluton of the Beaverhead Mountains (commonly called "Beaverhead pluton" and dated in Lund and others, 2010) and stock of Lemhi Pass (Gillerman and others, 2008) were emplaced as part of these extensional events; the intrusive rocks help provide timing for and location of a significant segment of this rift event. Paleozoic strata preserved in the map area were deposited on parts of the Lemhi arch, including some deposited on the inboard edge of the passive margin to the west and some in the paired intracratonal basin to the east. Formation of the arch resulted in a major Paleoproterozic-Paleozoic and Mesoproterozoic-Paleozoic angular unconformity across which Paleozoic strata were deposited. Paleozoic rock packages vary significantly across the map area in (1) thicknesses, (2) presence and position of erosional horizons, and (3) local and transitional facies - all related to punctuated rift activity and the resultant structurally unstable margin.

The map area lies in the hinterland of the Cretaceous thrust belt; thus, the Mesoproterozoic and Paleozoic rocks were complexly involved in east-directed, deep-seated compression. Mesoproterozoic rocks, with Paleozoic rocks piggybacking on top of them, caused basin inversion as the strata were stacked over the original basin margins on the eastern side of the mapped area. In this deformation, slivers of basement were also transported (Scholten and others, 1955; Scholten and Ramspott, 1968; M'Gonigle, 1994; M'Gonigle and Hait, 1997) and Mesoproterozoic and Paleozoic facies, deposited in a variety of settings, were juxtaposed.

Several phases of Tertiary extensional faulting also encompassed the range and reactivated or obliquely cut the preexisting structural geometries. Normal faults of this generation formed basins that localized and preserved Eocene volcanic rocks and Eocene through Miocene basin-fill deposits. The Beaverhead Mountains lie within the northern Basin and Range Province and the present topography formed during Miocene to Pleistocene(?) basin-and-range faulting.

\section{Present Study}

This map portrays detailed geology of the central Beaverhead Mountains at the 1:24,000 scale. Although the map is appropriate for use at 1:24,000 scale, it is prepared to be printed at 1:50,000 scale because of the large size of the study area. The initial geologic mapping for this study was carried out primarily between 1996 and 2002 and was generalized for incorporation in the geologic map of the Salmon National Forest (Evans and Green, 2003). Limited topical work was undertaken in subsequent years and resulted in minor stratigraphic reinterpretation but significant structural reinterpretation.

Previous studies have covered most of the study area (fig. 2). Those in the northern part of this map area were published in conjunction with studies of thorite deposits in the 


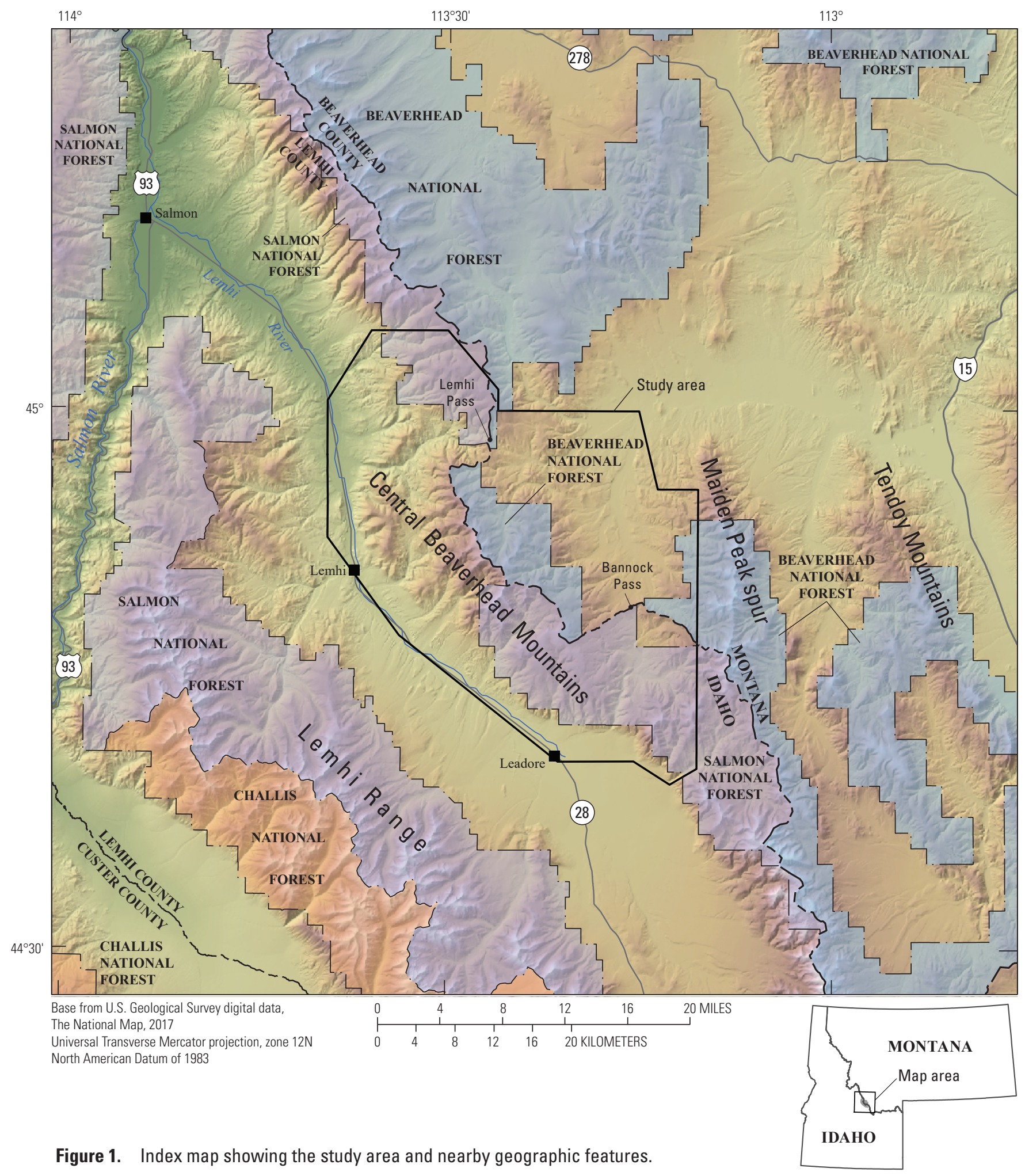

Lemhi Pass district (Staatz, 1972, 1973, 1979). Maps of the southern corner are presented in Lucchitta (1966) and Ruppel (1968). Quadrangle-scale geologic maps are available for the Maiden Peak spur (eastern margin of the map area and $20 \mathrm{~km}$ east, fig. 1) of the Beaverhead Mountains, overlapping the eastern edge of the present map area (M'Gonigle and others, 1991; M'Gonigle, 1994). Where the present map overlaps that of M'Gonigle (1994) and Lucchitta (1966), geologic contacts are modified and compiled; selected bedding and cleavage measurements from those authors are also shown on the map. Generalized geologic maps and attitudinal data for Cenozoic basin deposits east and west 


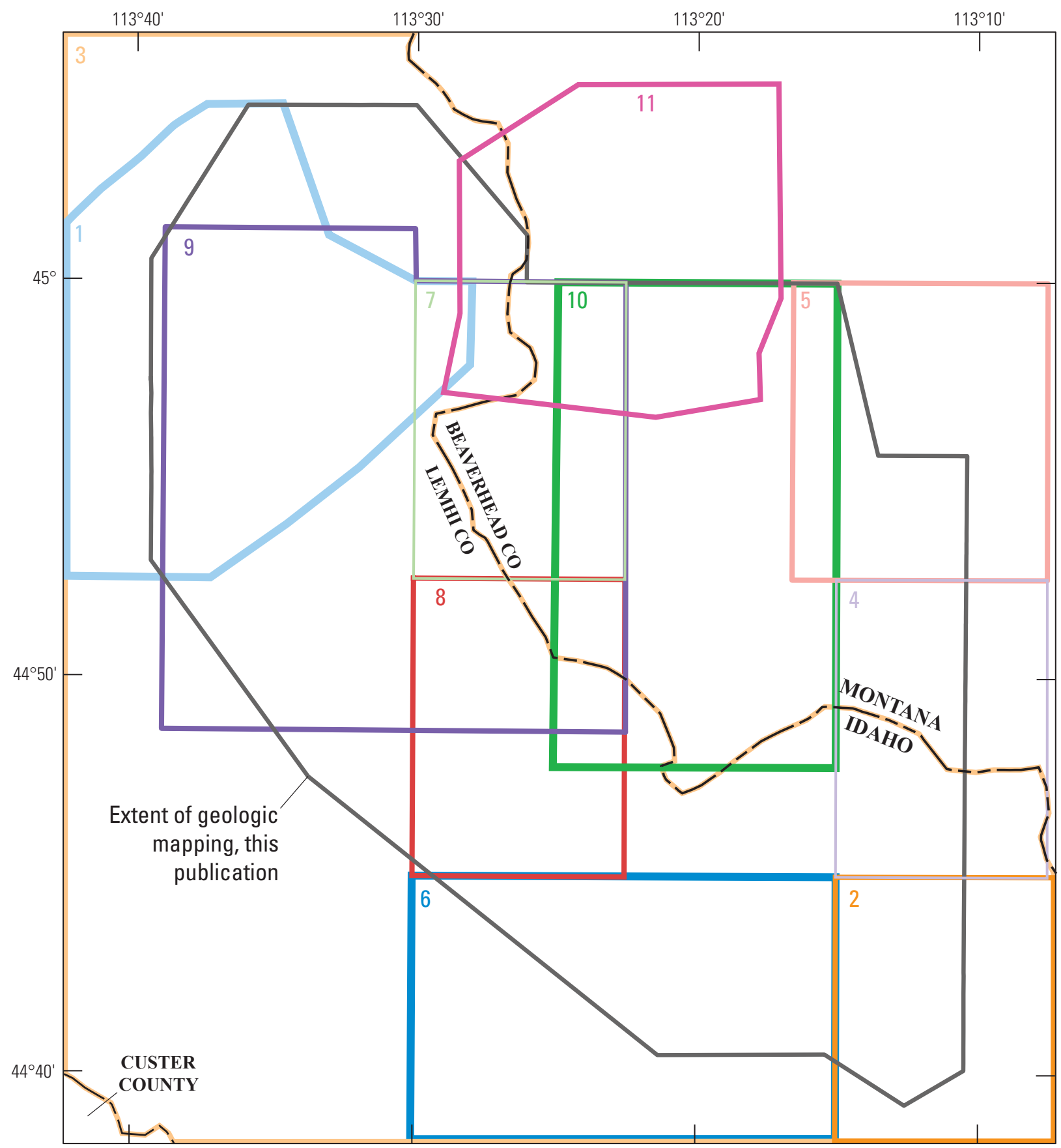

Figure 2. Index map showing areas of previous mapping in the study area. (1, Blankenau [1999]; 2, Lucchitta [1966]; 3, Lund and others [2003b]; 4, M'Gonigle [1994]; 5, M'Gonigle and Hait [1997]; 6, Ruppel [1968]; 7, Staatz [1972]; 8, Staatz [1973]; 9, Staatz [1979]; 10, VanDenburg [1997]; 11, Hansen [1983]).

of the range (VanDenburg, 1997; VanDenburg and others, 1998; Blankenau, 1999) are compiled with the new bedrock mapping to better illustrate the geologic development of the range in comparison to adjacent basins.

In comparison to the previous studies, the present map benefits from significant improvements in our understanding of regional Mesoproterozoic stratigraphic nomenclature and sedimentologic interpretation as well as of regional structural geometry (Tysdal 2000a, b, 2002, 2003; Evans and Green,
2003). The resultant, regionally integrated stratigraphic nomenclature was applied to this area by Lund and others (2003b). The present study provides specific details for these units in the Beaverhead Mountains and helps develop a regional picture of Mesoproterozoic basin geometries. The present map also incorporates modern, regional stratigraphic terminology and depositional interpretations for the Paleozoic rocks (Skipp and others, 1979a; Isaacson and others, 1983; Grader and Dehler, 1998). 
The collection of stratigraphic and structural data for the map area results in new interpretations of the stratigraphic relations, structural geometries, and structural history. To illustrate the stratigraphic settings and structural history, identified geographic areas containing a set of similar stratigraphic and structural characteristics are designated as structural domains. Locations and stratigraphy of domains are illustrated in figures 3 and 4.

\section{Depositional Settings of Mesoproterozoic and Paleozoic Rocks}

The Mesoproterozoic rocks in the map area are subdivided in this study into the Apple Creek (Yac) and Gunsight Formations $(\mathrm{Yg})$ (upper two formations in the Lemhi Group) plus the overlying Mesoproterozoic Swauger Formation (Ys) (Lund and others, 2003b). A total of about 3,500 meters (m) of these nonfossiliferous, fine-grained arkosic metasandstone and siltite rocks are in the map area. The general depositional settings for these three formations were below-wavebase-marine, fluvial, and tidal-marine environments, respectively (Tysdal, 2000b, 2003). The eastern margin of their depositional basin is exposed on the east side of the Beaverhead Mountains, $18 \mathrm{~km}$ east-southeast of Bannock Pass, where arkosic conglomerate and sandstone of the Gunsight Formation unconformably overlie Paleoproterozoic orthogneiss $(\mathrm{Xg})$ of the Wyoming basement province and the contact is undeformed (Tysdal and others, 2005).

This unconformity is also present in the southeast corner of the map area where it is characterized by minor shearing and chloritization due to decoupling during movement on the subjacent Cabin thrust fault. The PaleoproterozoicMesoproterozoic unconformity was previously mapped as a younger-on-older, possibly reactivated thrust "fault D" in the hanging wall of the Cabin thrust fault (M'Gonigle, 1994). Sediment transport was generally west directed, away from that basin margin, and the strata are finer grained and exhibit deeper-water depositional characteristics westward into the main basin (Tysdal and others, 2005). In the map area, this trend is most apparent in the Gunsight Formation, which contains finer grained and more biotite-rich rocks in the thrust plate in the western part of the range compared to rocks in the eastern thrust plate. In addition to the stratigraphic and sedimentologic data, detrital zircon dating of the sedimentary rocks (Lund and others, 2004; Link and others, 2007; Aleinikoff and others, 2012) shows that a significant portion of the zircon was sourced locally from Paleoproterozoic basement rocks generally east of the map area.

A particular characteristic of Mesoproterozoic units in the northern part of the study area is angular relations between the Gunsight Formation and the underlying Apple Creek Formation. This is exhibited in each of the several thrust plates of the northern and central map area. The discordance is manifested by a shallowly dipping, planar basal contact of the Gunsight Formation that truncates moderately dipping to overturned bedding as well as folds in the underlying Apple Creek Formation. In these cases, neither upright nor overturned folds, which deformed the Apple Creek rocks beneath the contact, are expressed in the overlying Gunsight and Swauger rocks. Additionally, preserved thicknesses of the Gunsight Formation between Apple Creek and Swauger Formations vary across the area. The Gunsight Formation bears extra-basinal conglomerate in nearby areas north and east of the map (Tysdal and others, 2005) as well as northwest of the map (Tysdal, 2003). These observations suggest that the Gunsight rocks were deposited across an angular unconformity. Although many aspects of the Apple Creek and Gunsight Formations remain little studied on a regional basis, detailed studies in the Lemhi Range indicates that contacts between units are generally gradational in that area (Tysdal, 2000b, 2003). Additionally, there are other indications that the top of the Apple Creek Formation is erosional in the northern Beaverhead Mountains and may be an unconformity on a regional scale (Tysdal and others, 2005). If that is the case, the amount of angularity between these two units increases eastward from the Lemhi Range to the Beaverhead Mountains.

Prior to deposition of Paleozoic rocks, Mesoproterozoic formations were tilted and eroded as a package, as demonstrated by the major angular unconformity at the base of the Paleozoic rocks. A likely cause of the deformation was formation of the Lemhi arch. Above the unconformity, Cambrian through Triassic strata were deposited on the flanks and across the top of the arch, and thus, in various depositional environments and water depths. Important characteristics of the local Paleozoic strata include the abrupt deepening of depositional environments from rocks of the Beaverhead Mountains to those of the Lemhi Range that is the next range to the west (Beutner and Scholten, 1967; Isaacson and others, 1983; Grader and Dehler, 1998; Lund and others, 2010) and discontinuous preservation and multiple unconformities in the lower Paleozoic section, both of which were caused by down-to-basin (down-to-west) fault activity related to the rifting of Rodinia, on the miogeoclinal (western) flank of the Lemhi arch (Grader and Dehler, 1998). Other evidence for the proximity of such structures to the map area includes the rip-up clasts in the unnamed Cambrian to Ordovician dolostone $(\mathrm{O} \in \mathrm{d})$ and the quartzite-clast conglomerate of the Neoproterozoic?-Lower Cambrian? quartz-pebble conglomerate to sandstone, herein referred to as the Neoproterozoic?Lower Cambrian? conglomerate $(€ Z c)$ as well as the limited preservation of these two units.

In the Goat Mountain domain (figs. 3 and 4), the unconformity is overlain by Lower Mississippian carbonate rocks from deeper water environments than most of the Paleozoic packages. Elsewhere in the map area, the MesoproterozoicPaleozoic unconformity is primarily overlain by Pennsylvanian to Permian strata. Across the Rocky Canyon fault in the Grizzly Hill domain, the unit above the unconformity changes relatively abruptly. West of the Rocky Canyon fault, the unconformity is overlain by Permian strata, but east of the fault, the unconformity is overlain by Upper Mississippian strata. The area where the change in units is manifested is 


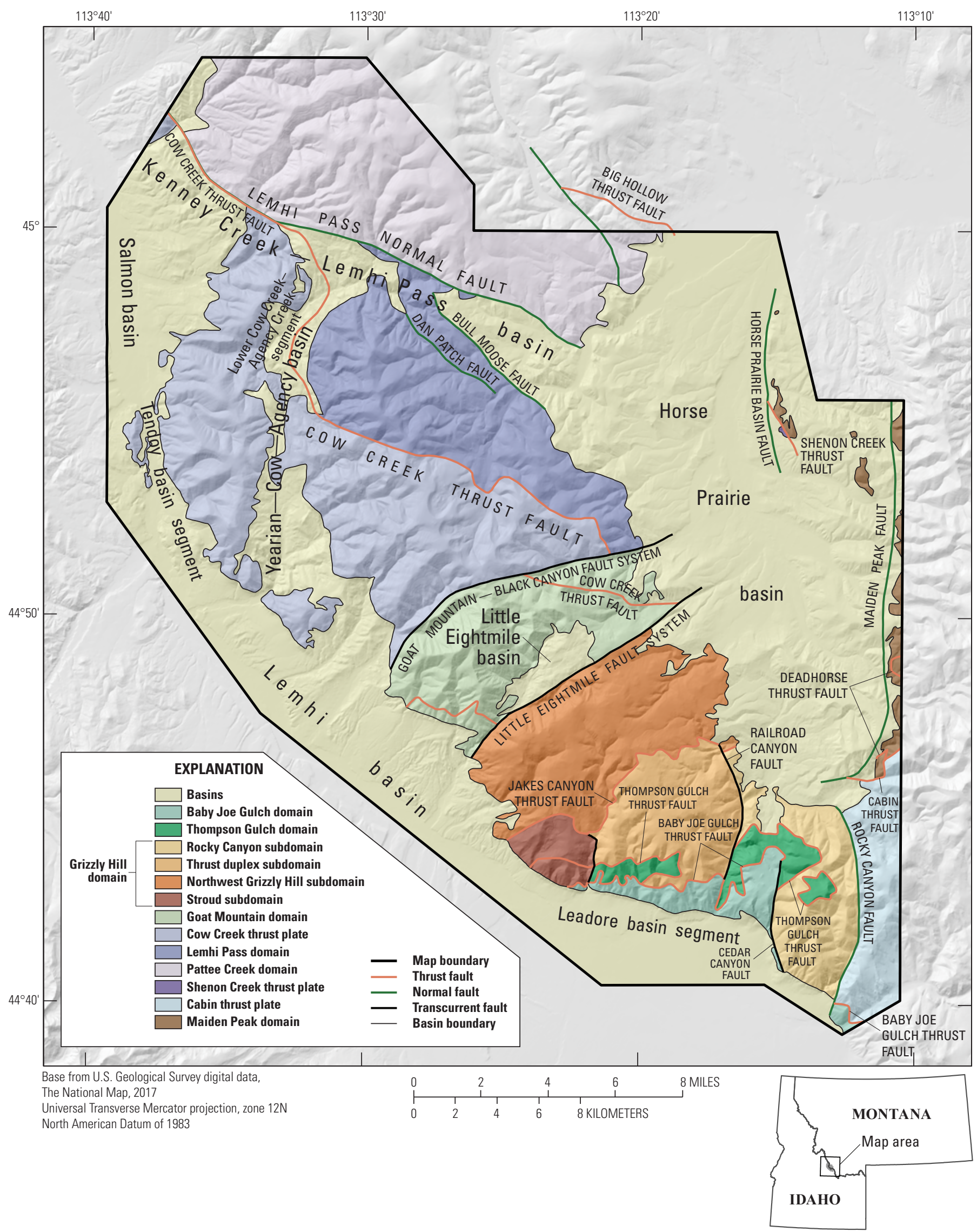

Figure 3. Index map showing locations of named structures, structural domains, and topographic features. 


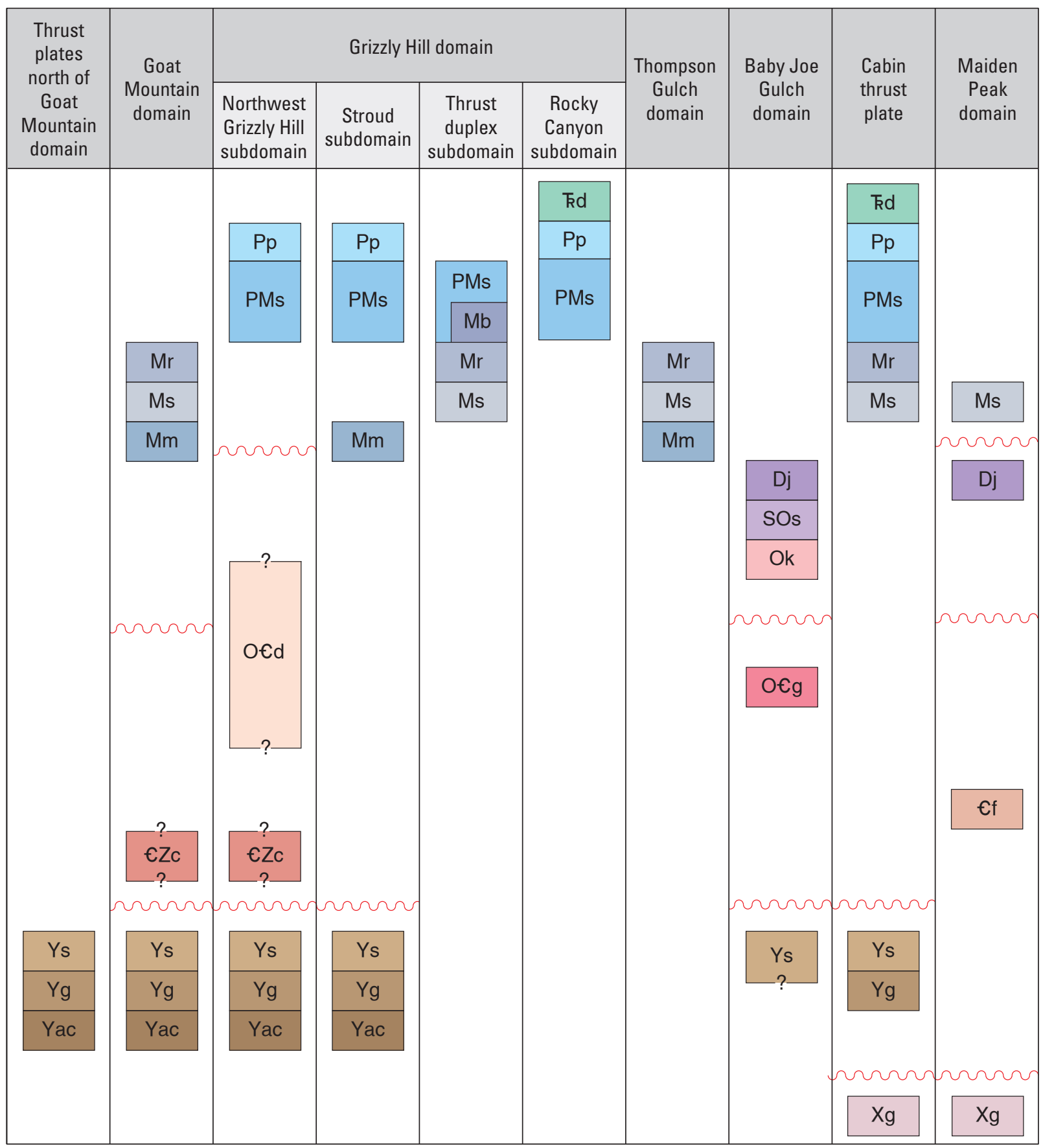

MESOZOIC TO NEOPROTEROZOIC? SEDIMENTARY

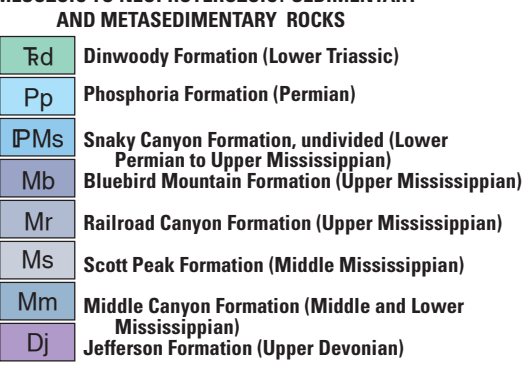

EXPLANATION

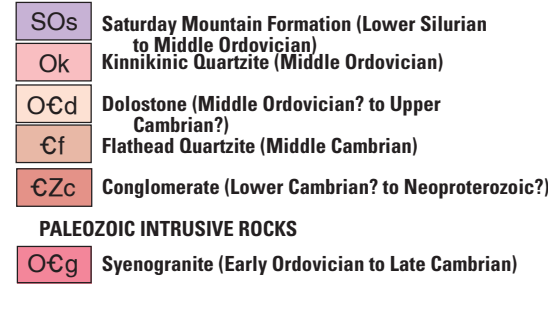

MESOPROTEROZOIC METASEDIMENTARY ROCKS

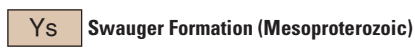

LEMHI GROUP

$\mathrm{Yg}$ Gunsight Formation (Mesoproterozoic)

Yac Coarse siltite unit of Apple Creek Formation (Mesoproterozoic) PALEOPROTEROZOIC INTRUSIVE ROCKS

$\mathrm{Xg}$ Orthogneiss (Paleoproterozoic)

$\backsim \sim$ Angular unconformity

Figure 4. Stratigraphic correlation chart for units in individual structural domains and subdomains. Location of domains, subdomains, and thrust plates are shown in figure 3. Column labeled "Thrust plates north of Goat Mountain domain" includes the Cow Creek thrust plate and Lemhi Pass and Pattee Creek domains plus Shenon Creek thrust plate. Wavy red lines indicate angular unconformities. 
covered, but the stratigraphic relations indicate that the Rocky Canyon fault reactivated a Paleozoic (and possibly also older) basin-margin fault.

Cambrian and Devonian units overlying Paleoproterozoic gneiss on the eastern margin of the map (Maiden Peak spur on fig. 1) were deposited in the cratonal basin setting. The stratigraphic section in the Maiden Peak spur (M'Gonigle, 1994) is significantly different from that of sections in the Beaverhead Mountains. Devonian strata are both in the Maiden Peak spur, where they overlie older cratonal basin strata, and in the Baby Joe Gulch domain (fig. 3), where they are in stratigraphic association with miogeoclinal units. The Upper Devonian Jefferson Formation overtopped the Lemhi arch (Sloss, 1954; Scholten, 1957) and was deposited over rocks of both settings. The Pennsylvanian and younger units were deposited over older units in transitional settings between those of the continental shelf and those of the cratonal basin (Skipp and others, 1979a).

The Paleozoic rocks of different depositional settings and, with different units overlying the unconformity, compose characteristic stratigraphic packages. In addition to discrete stratigraphy, the individual stratigraphic packages are generally delimited by faults and characterized by similar structural styles. The combined stratigraphic and structural characteristics are used to define discrete structural domains and subdomains.

The Goat Mountain domain contains Mississippian units that directly overlie Mesoproterozoic units along a sheared angular unconformity. The Mississippian section includes basal carbonate phyllite of the Lower to Middle Mississippian Middle Canyon Formation, massive limestone of the Middle Mississippian Scott Peak Formation, and carbonaceous shale of the Upper Mississippian Railroad Canyon Formation (Mm, Ms, and Mr, respectively). This Mississippian package formed on the outer carbonate banks of the continental shelf (Skipp and others, 1979b). The lack of Early Mississippian Antler orogenic sediments between them and the underlying Mesoproterozoic units demonstrates that this Mississippian section was deposited on a local pre-Mississippian high between the foreland basin to the west and the cratonal basin to the east (see model in Skipp and others, 1979b).

Distinctly different, thrust-bounded stratigraphic sections are in the Grizzly Hill domain. The structurally lowest thrust plate is the northwest Grizzly Hill subdomain (fig. 3), which contains the broadest age range for rocks at the base of the Paleozoic section. In this subdomain, Neoproterozoic?-Lower Cambrian? conglomerate (€Zc) or Cambrian(?) dolostone $(€ d)$ locally overlie the unconformity. The most widespread unit at or near the base of the Paleozoic section is the Upper Mississippian-Lower Permian Snaky Canyon Formation (PMs), an outer-carbonate-bank, miogeoclinal deposit (Skipp and others, 1979b). The overlapping Permian Phosphoria Formation exposed in the map area was deposited at the extreme western edge of the basin. The Phosphoria depositional basin was a sub-basin that developed late in the history of the Paleozoic miogeocline and was characterized by restricted sediment influx and nutrient-rich upwelling seawater (Wardlaw and Collinson, 1986). Structurally higher in the Grizzly Hill domain, the thrust duplex subdomain (fig. 3) carried Middle Mississippian Scott Peak to Upper Mississippian-Permian Snaky Canyon (Ms, Mr, Mb, and PMs). These units originated in a miogeoclinal shelf setting. The most distinctive characteristic about this stratigraphic section is the presence of the most complete exposure of the Railroad Canyon Formation (Mr type section, Wardlaw and Pecora, 1985). The Railroad Canyon Formation is a siltstone, shale, and calcisiltstone succession. It is interpreted to have been deposited in an intraramp extensional basin along the central shelf ramp. These intraramp rocks are flanked to both east and west by carbonate-rich deposits (Batt and others, 2007), and the structural setting presented herein changes the interpretation from a paleogeographic explanation to a structural juxtaposition of facies.

The composition of Upper Mississippian to Permian Snaky Canyon rocks changes across the Railroad Canyon fault. East of the fault, the Snaky Canyon Formation is relatively more quartz rich than equivalent rocks west of the fault. The three members recognized west of the fault are difficult to recognize east of the fault using the same criteria, suggesting the presence of different facies. In the eastern part of the area, these rocks were originally mapped by Lucchitta (1966) as the Upper Mississippian to Permian Quadrant Formation. The present mapping suggests that these more quartz-rich rocks are probably a transitional facies between the Snaky Canyon Formation of the central miogeoclinal ramp and the Quadrant Formation of the eastern (upper) ramp (Skipp and others, 1979b).

Three distinctly different stratigraphic packages structurally overlap the subdomains of the Grizzly Hill domain (fig. 3). The Thompson Gulch domain contains the structurally lowest of these stratigraphic packages and is characterized by phyllitic rocks of the Lower to Middle Mississippian Middle Canyon Formation (Mm). The Middle Canyon Formation in this domain is a greenschist facies, isoclinally folded tectonite in which stratigraphic details are obscured. This metamorphic fabric contrasts with the general lack of tectonic fabric in the same unit in the Goat Mountain domain.

The Baby Joe Gulch domain structurally overlies the Thompson Gulch domain and contains unmetamorphosed Middle Ordovician Kinnikinic Quartzite (Ok), Middle Ordovician to Lower Silurian Saturday Mountain Formation (SOs), and Upper Devonian Jefferson Formation (Dj). This is the only domain containing the Jefferson Formation in the main part of the central Beaverhead Mountains and its presence indicates that the Jefferson was deposited unconformably over Ordovician strata in this setting. This package of rocks was transported eastward, telescoping deeper water shelf sections onto shallower water (upper-shelf) sections. The highest thrust fault of the Baby Joe Gulch domain transported a large thrust sliver of Late Cambrian to Early Ordovician Beaverhead pluton, which is nonconformably overlain by Middle Ordovician Kinnikinic Quartzite and Middle Ordovician to Lower Silurian Saturday Mountain Formation (this study; Lund and others, 2010). The units in these upper two domains originated in distinctly different settings in comparison to other Paleozoic rocks in the map area. 
The depositional settings of Paleozoic rocks in the central Beaverhead Mountains were markedly different from the setting of equivalent units in the Maiden Peak spur (fig. 1), where lower Paleozoic strata were deposited unconformably on Archean and Paleoproterozoic rocks (M'Gonigle and others, 1991; M'Gonigle, 1994). In the Maiden Peak spur, basal Paleozoic rocks locally include the Middle Cambrian Flathead Quartzite (€f) and (or) Wolsey Shale (not present in the map area) of the cratonal basin or the Upper Devonian Jefferson Formation that is found in both miogeoclinal and cratonal basin settings; the Upper Cambrian-Silurian section is missing between Middle Cambrian and Devonian rocks.

The present mapping determined that different amounts of time are represented by the gap in the rock record along the Mesoproterozoic-Paleozoic unconformity. On the east side of Horse Prairie basin, the unconformity represents a gap in time of about 2 billion years (Paleoproterozoic gneiss at $2.45 \mathrm{Ga}$ overlain by Middle Cambrian rocks at about 510 mega-annum [Ma] or Devonian rocks at about $385 \mathrm{Ma}$ ). In the five thrust plates carrying Paleozoic strata in the map area, the stratigraphic gaps beneath the unconformity include missing rocks between the Mesoproterozoic (about $1.4 \mathrm{Ga}$ ) formations and locally the Neoproterozoic-Lower Cambrian conglomerate (€Zc), the Lower to Middle Mississippian Middle Canyon Formation (Mm), the Middle Mississippian Scott Peak Formation (Ms), or the Upper Mississippian-Lower Permian (359-326 Ma) Snaky Canyon Formation (PMs) in different domains (fig. 4). Prior to the present mapping, these basal angular unconformities were interpreted as Paleocene to early Eocene normal faults excising different parts of the Paleozoic section (Janecke and others, 2001).

\section{Settings of Cenozoic Deposits}

The Challis Volcanic Group is the manifestation of widespread, Eocene (about 52-45 Ma) crustal extension in the area north of the Snake River Plain, Idaho, into Canada. These volcanic rocks and related orogenic sediments were deposited in synextensional fault-bounded basins (fig. 3). On the west side of the Beaverhead Mountains, the main southern depocenters included the Tendoy basin segment and the Lemhi basin, both part of the Lemhi River drainage that empties into the complex, north-striking Salmon basin (Harrison, 1985); on the east, the main depocenter was the Horse Prairie basin (fig. 3). Lesser fault graben and depocenters include the narrower Kenney Creek-Lemhi Pass, Yearian-Cow-Agency, and Little Eightmile basins that obliquely transect the range in different orientations. Successive changes in basin geometries caused differences in the age and volume of deposits among the basins (VanDenburg and others, 1998; Janecke and others, 2001). The latter part of the progression reflects initiation of the present basin-and-range topography.

The timing of onset and early history of basin development are constrained by detailed studies of the volcanic successions (Staatz, 1979; M'Gonigle, 1994; M'Gonigle and Hait, 1997; VanDenburg, 1997; Blankenau, 1999). The Kenney Creek-Lemhi Pass basin, a structural paleovalley that obliquely transects the range in a southeasterly direction (fig. 3), hosts the oldest part of the volcanic succession. The deposits in this early graben system include basal conglomerate, tuffs with conglomerate zones, and thick dacite flows.

A younger succession of tuffs, a thick andesite flow unit, and overlying sandstone were deposited in both the previously active northwest-striking Kenney Creek-Lemhi Pass basin and the younger, north-striking Tendoy basin segment; equivalent tuffs and conglomerates were deposited in the north-striking Horse Prairie basin.

The youngest part of the volcanic succession is predominantly tuffaceous rocks, including the regionally recognized tuff of Curtis Ranch at the base. This young package is restricted to the north-striking Tendoy basin segment and Horse Prairie basin but is thicker in the Horse Prairie basin where several dacite flow units and interlayered tuffs and conglomerates are at the top of the section.

Samples of volcanic rocks from the Horse Prairie basin have been dated. Near the base of the section there, ages are about $48.6 \mathrm{Ma}$; near the upper part of the section, an age of 46.0 Ma was determined (M'Gonigle and Dalrymple, 1993; VanDenburg and others, 1998).

Challis Volcanic Group is also preserved in the northeast-striking Little Eightmile basin and in local faultbounded exposures along the range crest nearby. These volcanic rocks remain undated so the relations between them and the larger exposures are unclear. However, the perched deposits in southeast-striking paleobasins indicate that the volcanic rocks originally were more widely distributed above the older rocks and were deposited more widely across older bedrock and not restricted to the basin settings where they are best preserved at present.

In addition to the Challis Volcanic Group, the structural basins of the Beaverhead Mountains also contain as many as three unconformity-bounded sequences of orogenic sedimentary deposits. These range in age from late Eocene to Miocene. The sequences have different characteristics in the different basins and through time, reflecting deposition punctuated by coeval normal faulting and tilting (VanDenburg and others, 1998).

The oldest unconformity-bounded sequences are Eoceneto Oligocene-age deposits in the large basins on both sides of the range ( $\mathrm{Tsl}$; called sediments of Bear Creek in the Horse Prairie basin, VanDenburg and others, 1998). The sediments range in grain size from cobble conglomerate to tuffaceous shale and contain interlayered gastropod-bearing, lacustrine limestones. The early Kenney Creek-Lemhi Pass and YearianCow-Agency basins, which transect the range, locally contain thin deposits of the same unconformity-bounded sequence (Staatz, 1979; Blankenau, 1999).

The middle unconformity-bounded sequences are composed of middle Oligocene- to Miocene-age deposits. On the west side of the Beaverhead Mountains between Sandy and Kenney Creeks, these are cobble to boulder conglomerates 
(Blankenau, 1999), which were deposited along the active range-front fault at the southern end of the Salmon-basin detachment fault of Janecke and others (1998). On the east side of the mountain range, in the Horse Prairie basin, faulting was less active and the middle unconformity-bounded sequence (dated at 30 to 19 Ma by VanDenburg and others, 1998) was deposited in a more quiescent setting. Here, it is composed of clastic deposits ranging in grain size from pebble conglomerate through shale and contains thin limestone lenses. This unit is called "the sediments of Everson Creek" by M'Gonigle (1994), VanDenburg and others (1998), and Blankenau (1999).

The youngest unconformity-bounded basin-fill deposits are those called mudstone deposits (Tm) and formed in a paleobasin near Bannock Pass in the southern Horse Prairie basin. This young sequence contains a 16-12 Ma, relatively fine-grained succession (M'Gonigle 1994; VanDenburg and others, 1998). Approximate age-equivalent deposits are in the Lemhi basin as well (VanDenburg and others, 1998).

Within Cenozoic deposits in the southern part of the Yearian-Cow-Agency basin are linear outcrops of brecciated Mesoproterozoic rocks belonging to either the Apple Creek or Gunsight Formation. They form east-dipping ribs about 200-400 m wide, several of which directly abut or overlie the volcanic rocks; other ribs of the brecciated Mesoproterozoic rocks are surrounded by valley-fill deposits. These exposures of brecciated Mesoproterozoic rocks are interpreted to be Eocene to Miocene slide blocks (megabreccia) transported into the southern segment of the Yearian-Cow-Agency basin during basin development.

\section{Deformation History}

The rocks were affected by multiple, diverse deformation events. Late Cretaceous compressional deformation and Cenozoic extensional events are recognized in the broader region, but pre-Cretaceous structural events are not well documented. Faults related to Mesoproterozoic extension, which downdropped the Mesoproterozoic Lemhi basin relative to the uplifted Paleoproterozoic basement rocks, have not been identified in the field. Similarly, although Neoproterozoic-early Paleozoic rifting and formation of the Lemhi arch controlled miogeocline geometries and deposition in and adjacent to the map area, related structures also remain unidentified. Either or both of these extensional events might have caused the tilting of Mesoproterozoic strata beneath the Paleozoic unconformity in the study area.

Potential Mesoproterozoic deformation is represented by moderately dipping to overturned bedding and folds in the Apple Creek Formation, features which are not expressed in the overlying Gunsight and Swauger rocks. These characteristics of the contact are widespread in each of the several Cretaceous-age thrust plates in the northern and central parts of the study area. These examples of discordant bedding suggest that a deformation event interrupted Mesoproterozoic sedimentation. However, corollary evidence for geometry and age of a pre-Gunsight Formation Mesoproterozoic fold event, manifested primarily in the Beaverhead Mountains exposures, needs further study.

The entire Mesoproterozoic section was tilted, possibly gently folded, and exposed to erosion prior to deposition of the Paleozoic rocks. These relations are evidence of deformation before Cambrian or later Paleozoic sedimentation, depending on the location. One likely cause for deformation of Mesoproterozoic rocks prior to Paleozoic sedimentation is Neoproterozoic to Late Cambrian-Early Ordovician extension during breakup of the supercontinent Rodinia (Lund and others, 2010). Across the region, early Paleozoic units show significant differences in thickness between the Beaverhead Mountains near the axis of the Lemhi arch and deeper water units in the Lemhi Range, as recognized from stratigraphic studies (Beutner and Scholten, 1967; James and Oaks, 1977; Isaacson and others, 1983; Ruppel and Lopez, 1988). The differences in stratigraphy and depositional water depth indicate that major down-to-the-west, basin-bounding normal faults existed between those two depositional settings (Isaacson and others, 1983; Grader and Dehler, 1998). One structure of this type is inferred in the southern part of the map, where there is a significant change in which unit overlies the Mesoproterozoic-Paleozoic unconformity across the Rocky Canyon fault. Permian rocks overlie the unconformity west of the fault but Mississippian rocks overlie the unconformity east of the fault (across an interval of about $7.4 \mathrm{~km}$ [4.6 mi] between these Paleozoic exposures near the southern edge of Horse Prairie basin). This change indicates the location of a generally northstriking, down-to-the-west, Mississippian-Pennsylvanian synsedimentary growth fault.

\section{Pre-Cretaceous Deformation}

The contact between Apple Creek and Gunsight Formations is interpreted as an angular unconformity on this map because, in several places, the Apple Creek Formation is folded at outcrop to kilometer scales but overlain by unfolded Gunsight Formation. This indicates Mesoproterozoic-aged deformation. The Mesoproterozoic units are also broadly arched beneath the Paleozoic unconformity, providing further indication of Mesoproterozoic or Neoproterozoic deformation. The contact between Apple Creek and Gunsight Formations in the structural domain that lies in the footwall to the Cow Creek thrust fault is characterized by pervasive cleavage and is cut by many small quartz veinlets. The shearing may have been caused by decoupling related to broad arching of the Mesoproterozoic formations because evidence of tectonic transport along the contact is lacking. Both the arching of Mesoproterozoic units and the sheared Apple Creek-Gunsight contact are found in several different Cretaceous structural domains, suggesting that the decoupling predated Cretaceous thrust faulting. 


\section{Cretaceous Compressional Structures}

\section{Predominantly Proterozoic Domains}

The Apple Creek-Gunsight contact mapped in this study closely matches the location of a thrust fault mapped by Staatz (1973) and Ruppel (1978) and of the "Medicine Lodge thrust fault" of Ruppel (1978), Ruppel and Lopez (1984), Ruppel and others (1993). The present mapping indicates that the contact in the central Beaverhead Mountains is a sheared unconformity, but evidence was not found to substantiate the presence of the Medicine Lodge thrust fault. In the Maiden Peak spur, the Paleoproterozoic-Mesoproterozoic contact ("fault D" of M'Gonigle, 1993, 1994) is shown as part of the Medicine Lodge thrust fault (Ruppel, 1978), but this contact is reinterpreted as an unconformity (Tysdal and others, 2005). The Medicine Lodge thrust fault was also shown in the Lemhi Range and northern Beaverhead Mountains by Ruppel (1978) and Ruppel and Lopez (1984), but more recent mapping reveals that a thrust fault of this type does not exist in those areas either (Tysdal, 2002; Tysdal and others, 2005, respectively). Thus, a youngeron-older Medicine Lodge thrust fault has not been substantiated in any of the areas where it was originally depicted, including in the central Beaverhead Mountains.

\section{Maiden Peak Domain}

\section{Deadhorse Thrust Fault}

The structurally lowest thrust fault is exposed east of the Horse Prairie basin on the western flank of the Maiden Peak spur (Maiden Peak domain on figure 3). There, Paleoproterozoic basement orthogneiss was faulted over the Upper Devonian Jefferson Formation along a north-striking thrust fault (M'Gonigle, 1994). A number of thrust slivers with similar relations are mapped across the Maiden Peak spur directly east of the present map (M'Gonigle, 1994; M'Gonigle and Hait, 1997). Another exposure of these is in a structural window along Deadhorse Canyon at the eastern map boundary. There, a small window of Mississippian limestone is juxtaposed beneath Paleoproterozoic granite gneiss (reinterpreted from M'Gonigle, 1994). These east-directed thrust slivers of basement rocks are oblique to, structurally overlapped by, and therefore probably older than the rest of the thrust faults in the study area.

\section{Shenon Creek Thrust Fault}

South of the Shenon Creek drainage on the eastern edge of the Horse Prairie basin, small exposures of older rocks beneath Cenozoic units reveal a thrust fault that placed Mesoproterozoic Gunsight over probable Mississippian limestone and Cambrian(?) quartzite-pebble conglomerate. This Shenon Creek thrust fault (fig. 3) is the northeasternmost thrust fault that transported rocks of the Lemhi Group. Because of the amount of normal-fault activity that formed the Horse Prairie basin, direct connections between this thrust fault and others in the map area cannot be determined.

\section{Cabin Thrust Plate}

Adjacent to and structurally above the Deadhorse Canyon window is the regionally persistent, east-striking Cabin thrust fault (fig. 3). It crosses the southern end of the Maiden Peak spur and is named for exposures directly east of the map area (Scholten and others, 1955; Tysdal and others, 2005; reinterpretation of fault C of M'Gonigle, 1993, 1994; M'Gonigle and Hait, 1997; note that use of "Cabin thrust fault" and "Cabin thrust plate" herein is more restricted than that of Skipp, 1987). The hanging wall contains Mesoproterozoic Gunsight Formation unconformably overlying Paleoproterozoic granite basement gneiss and the footwall contains small remnants of Cambrian quartzite to Devonian carbonate that had been deposited directly on Paleoproterozoic gneiss (Scholten and others, 1955; M'Gonigle, 1994). The Cabin thrust fault is north- or northeast-vergent, and it is important for several reasons: (1) it lies at the geographic junction between the Maiden Peak spur and the Beaverhead Mountains, where it bounds very different stratigraphic and structural domains; (2) it is nearly perpendicular to and overlying a set of directly subjacent, north-striking thrust faults of the Maiden Peak spur (M'Gonigle, 1993, 1994); and (3) it transported thick sections of Mesoproterozoic arkosic metasandstone and quartzite of the Gunsight and Swauger Formations with a thin sliver of their basal, unconformable contact with Paleoproterozoic gneiss (Tysdal and others, 2005) over a footwall that contains Paleozoic rocks lying on gneiss with no Mesoproterozoic strata preserved (M'Gonigle, 1994; M'Gonigle and Hait, 1997). As such, this is a key thrust fault that transported strata from the Mesoproterozoic Lemhi basin onto the Mesoproterozoic-Paleozoic basement high of southwestern Montana.

Because of the significant Cenozoic normal-fault displacement related to formation of the Horse Prairie basin, the Big Hollow thrust fault (fig. 3) mapped adjacent to the northeastern corner of the map area by Hansen (1983) could connect with the Cabin thrust fault or, because of changes in basement or basin geometries within the map area, footwall and hanging wall relations may vary significantly along the fault such that the fault may have stepped up section to the northeast in a manner described by Skipp (1985) from the adjacent area to the south.

\section{Cow Creek Thrust Plate}

The large, relatively well-exposed Cow Creek thrust fault crosses much of the map area, from the northwestern corner to the east-central area (fig. 3). The main segment is relatively well exposed and is manifested by Apple Creek Formation juxtaposed over Gunsight Formation strikes southeast-northwest for about $17 \mathrm{~km}(11 \mathrm{mi})$ across the range from upper Cow Creek in Idaho to Nip and Tuck Creek in Montana. For several kilometers away from the fault in both the hanging wall and footwall, rocks are characterized by complex ductile deformation fabrics. In footwall rocks (Lemhi Pass domain, fig. 3), phyllitic foliation or pervasive cleavage are most well 
developed for about $1 \mathrm{~km}$ from the fault trace. Bedding in footwall rocks was deformed into northwest-striking open folds, and cleavage is primarily southwest dipping, both generally parallel to the Cow Creek thrust fault. In hangingwall rocks (Cow Creek thrust plate, fig. 3), phyllitic foliation or pervasive cleavage are superimposed on bedding for about $5 \mathrm{~km}$ from the fault trace. Although upright bedding generally dips east and overturned bedding generally dips west, the foliation consistently strikes northwest and dips moderately southwest, parallel to the trace of the Cow Creek thrust fault.

A northwest-striking, northeast-vergent overturned anticline (traced for about $3.7 \mathrm{~km}$ [2.2 mi]) parallels the Cow Creek thrust fault in its hanging wall along much of the main range-crest segment. The fold is characterized by overturned bedding and by a broad zone of pervasive, northwest-striking, southwest-dipping, axial-planar cleavage and phyllitic foliation. The overturned limb of the fold is partly truncated by an unnamed, minor thrust fault (traced for about $6.2 \mathrm{~km}$ [3.8 mi]) within the Apple Creek Formation section. Elsewhere in the hanging wall, well-developed foliation and the spaced cleavage that overprinted the foliation both consistently strike north and dip west. The hanging wall is also characterized by numerous east-overturned, minor folds that deformed bedding.

Whereas the main segment of the Cow Creek thrust fault strikes northwest across the range to Cow Creek, the fault changes direction and strikes north along lower Cow Creek and northeast along the central reaches of Agency Creek for $6.5 \mathrm{~km}(4 \mathrm{mi})$. Although the amount of fault separation along the lower Cow Creek-Agency Creek segment (fig. 3) was reduced by several normal faults and this segment is largely buried beneath rocks of the Challis Volcanic Group, two lines of evidence indicate the location of this cryptic segment of the Cow Creek thrust fault: (1) older rocks of the Apple Creek Formation remain on the western (hanging wall) side of the fault relative to the upper Apple Creek and Gunsight Formations on the east (footwall) side, and (2) the fault system is paralleled by map-scale folds in footwall rocks.

Another northwest-striking segment of the Cow Creek thrust fault, also largely concealed beneath Cenozoic volcanic and basin deposits, is present along Gould Basin and as far northwest as Kenney Creek (more than $12 \mathrm{~km}$ [7.5 mi] long). The fault is exposed in and near central Pattee Creek, where it is defined by older-over-younger relations of Apple Creek Formation juxtaposed over Gunsight Formation. In another small exposure of hanging-wall rocks of the Cow Creek thrust fault, complexly deformed Apple Creek Formation rocks and older-on-younger relations can be interpreted by projecting units across lower Kenney Creek. Much of the offset on this Pattee Creek segment was reduced by Cenozoic normal faulting, particularly along the western extent of the Lemhi Pass normal fault.

Geometries of the segments of the Cow Creek thrust fault indicate that, relative to the main segment and the Pattee Creek segment, the lower Cow Creek-Agency Creek segment is a down-to-the-north step that was a lateral ramp or tear fault during compression.
Several megascopic, open folds in bedding are in the Apple Creek and Gunsight Formations of both the hanging wall and footwall of the Cow Creek thrust fault. Fold axes are parallel to the local adjacent strike of the thrust fault. One large fold east of Agency and Cow Creeks has a curvilinear trace that describes a north- through northwest-striking arc. The arcing fold lies in the footwall of the Cow Creek thrust fault, and the fold arc parallels the trace of the main segment of the Cow Creek thrust fault and its lower Cow CreekAgency Creek ramp or tear segment.

${ }^{40} \mathrm{Ar} /{ }^{39} \mathrm{Ar}$ analysis of metamorphic white mica and biotite in the thrust-fault-related fabrics of Mesoproterozoic strata produced complex age data (Lund and others, 2004). The age data showed that the micas were not detrital (they are younger than the about $1.4 \mathrm{Ga}$ age of the rocks) rather, that the micas formed during younger regional metamorphic events. The age data are complex; they do not reveal a consistent age for the mica formation or for the structural events in which they grew.

\section{Southern, Predominantly Paleozoic Domains}

In the southeastern part of the map area, where Paleozoic strata were involved in Cretaceous deformation, transport was also northeast directed but structural domains had complicated rotational motions relative to each other. However, the details of style and geometry of compressional structures are different from those developed in the domains encompassing Mesoproterozoic strata in the northern part of the map area. Southeastern structural domains are demarcated by steeply dipping, curvilinear compressional structures.

\section{Goat Mountain Domain}

The Goat Mountain domain is defined by a curvilinear set of compressional faults, which control the drainages of Black Canyon and Peterson Creek, and by a related set of faults bracketing Goat Mountain (generalized as "Goat MountainBlack Canyon fault system" in figure 3). These related strands have southeast-dipping, listric geometries. The western extents of these faults exhibit geometries that are consistent with sinistral, transpressional movement, whereas the northeastern extents of the faults exhibit components of older-on-younger (reverse fault) offset. Several fault strands were reactivated by Eocene or younger, down-to-the-southeast, normal displacement. The Mississippian strata, which are part of the Goat Mountain domain, were unconformably deposited on Mesoproterozoic strata. These Mississippian rocks originated from an outer-shelf miogeoclinal setting in contrast to the strata that primarily overlie the unconformity in the domain to the east (Grizzly Hill domain, fig. 3), which represent shelf transitional to cratonal settings of the Upper Mississippian to Permian system. Thus, the Mississippian strata as well as the underlying Mesoproterozoic strata in the Goat Mountain domain originated in deeper water settings (farther west) than most other stratigraphic sections in the map area. This structural interpretation is significantly different from published maps 
and reconnaissance studies because, in one interpretation, the Mesoproterozoic unconformity was depicted as a thrust fault (Staatz, 1973; Ruppel, 1978) and, in another interpretation, this angular unconformity was depicted as a normal fault (called "Goat Mountain fault" in Janecke and others, 2001).

\section{Grizzly Hill Domain}

Another large curvilinear compressional fault system bounds a complex thrust domain herein named the "Grizzly Hill domain" and extending from Little Eightmile fault system to the Rocky Canyon fault (fig. 3). The curvilinear fault system, parallel to and southeast of Little Eightmile Creek, juxtaposed Apple Creek and Gunsight Formations of the Grizzly Hill domain against the Mississippian rocks of the Goat Mountain domain. Although largely obscured by the Cenozoic deposits that fill Little Eightmile Creek, the bounding fault system underwent sinistral oblique reverse offset. The Grizzly Hill domain is underlain by the Mesoproterozoic formations and Paleozoic units of a broad range of ages atop the Mesoproterozoic-Paleozoic unconformity. The Mesoproterozoic-Paleozoic unconformity in the Grizzly Hill domain was previously interpreted as a normal fault (named the "Grizzly Hill fault" in Janecke and others, 2001).

Between Little Eightmile Creek and Mollie Gulch, the Apple Creek Formation was deformed into a large, northeastvergent, overturned, megascopic anticline expressed by progressive eastward overturning of bedding and associated southwest-dipping, axial-planar foliation in the Apple Creek Formation (cross section $B-B^{\prime}$ ). The overlying Gunsight Formation was not involved in the folding of the Apple Creek Formation; this provides evidence from the southern part of the map area as well as from the northern for possible Mesoproterozoic deformation before deposition of the Gunsight Formation. Additionally, the depositional contact of Paleozoic units over all three Mesoproterozoic units is widely preserved in the Grizzly Hill domain, indicating Precambrian-age tilting of the older rocks before Paleozoic deposition. On previous maps, several thrust and normal faults were interpreted within the Mesoproterozoic section (Staatz, 1973; Ruppel, 1978; and Janecke and others, 2001); additionally, the MesoproterozoicPaleozoic unconformity in the Grizzly Hill domain was previously named the Grizzly Hill fault (Janecke and others, 2001). The interpretations herein are significantly different from those previous.

The major compressional structure of the Grizzly Hill domain is the Jakes Canyon thrust fault. The Grizzly Hill domain is subdivided into three subdomains by (1) structural complications related to lateral ramps and tear faults in the hanging wall of the Jakes Canyon thrust fault and (2) a structural geometry whereby the units above the Mesoproterozoic-Paleozoic unconformity change across the ramp or tear faults. Each subdomain is identified by significantly different structural geometries and by disparate Paleozoic sections.

The Stroud subdomain, at the western extent of the Jakes Canyon thrust fault, is a compound thrust sliver that double stacked the Mesoproterozoic-Permian unconformity.
This subdomain is bounded on the northwest by an oblique reverse fault and contains two associated minor thrust slivers (fig. 3). In the structurally lowest rocks of the subdomain, the Mesoproterozoic-Permian contact zone was anticlinally folded. The Stroud subdomain terminates on the east along a lateral ramp in Jakes Canyon. The upper thrust fault of the Stroud subdomain (carrying Middle Canyon Formation and Mesoproterozoic strata) and the Thompson Gulch thrust fault (fig. 3) may be kinematically linked.

The other two subdomains of the Grizzly Hill domain are composed of the same Mississippian to Lower Permian units but have different structural characteristics on either side of the Railroad Canyon fault. The larger of the subdomains, herein called "thrust duplex subdomain," is bounded by the Jakes Canyon thrust fault on the west and north and by the Railroad Canyon fault, a lateral ramp. The main characteristic of this subdomain is a complex stack of imbricate-thrust slivers forming a hinterland (generally west)-dipping thrust duplex (cross section $C-C^{\prime}$ ) that is confined to this subdomain. The Rocky Canyon subdomain, east of the Railroad Canyon fault, is overlapped by Cenozoic deposits of the southern Horse Prairie basin east of Hood Gulch, so the Jakes Canyon thrust fault and the unconformity in its footwall are exposed only at the northeastern corner of the subdomain. Although both the thrust duplex and Rocky Canyon subdomains contain the same basic stratigraphy, the Rocky Canyon subdomain does not contain the hinterland-dipping thrust duplex, so it is simpler and thinner than the thrust duplex subdomain. The structural differences in the subdomains on either side of the Railroad Canyon fault document that the geometry of the fault is a lateral ramp in the Jakes Canyon thrust fault.

The Rocky Canyon fault is a down-to-the-west normal fault that forms the eastern boundary of the Rocky Canyon subdomain. Although the offset on the Rocky Canyon fault is relatively minor in the southern part of the fault, offset is significantly greater across the northern part, where Pennsylvanian strata of the Rocky Canyon subdomain are juxtaposed against Mesoproterozoic strata of the Cabin thrust plate. A small exposure of Phosphoria Formation on the east side of the Rocky Canyon fault (originally called a klippe by Lucchitta, 1966) is probably a remnant of the Mesoproterozoic-Paleozoic unconformity as present throughout the Grizzly Hill domain. South of the Phosphoria exposure, Middle Mississippian Scott Peak Formation directly overlies Mesoproterozoic strata along a faulted contact. Based on those stratigraphic and structural relations, the Jakes Canyon thrust fault either wedged out eastward or changed stratigraphic levels across the Rocky Canyon fault. This change of thrust fault character is at the edge of the Precambrian high as documented throughout the Cabin thrust plate (Scholten and others, 1955; Lucchitta, 1966; Skipp, 1985), and the presence of the basin margin may have caused the northeast-vergent Jakes Canyon thrust fault to cut structurally down from Paleozoic rocks in the Grizzly Hill domain into Proterozoic rocks to the east. Similar structural geometries of stepped-up-to-the-east Paleozoic basin margin, which were cut and transported by the Cabin thrust fault, 
were used to explain changes in ages of hanging wall and footwall rocks along the Cabin thrust fault for a nearby area to the south (Skipp, 1985). The fault carrying the Mississippian and younger units may also have been reactivated by a low-angle normal fault, as shown by Lund and others (2003b), and may continue to the south as part of the Divide Creek fault (Lucchitta, 1966; note that the Divide Creek fault does not continue to the north of the Wildcat fault as depicted in Janecke and others, 2001).

\section{Thompson Gulch Domain}

The southern margin of the thrust-duplex and Rocky Canyon subdomains, as well as the Railroad Canyon lateralramp fault, are overlapped by the west-striking Thompson Gulch thrust fault. This fault superimposed older and more distal Middle Canyon Formation over Upper Mississippian to Permian strata. The Middle Canyon strata were metamorphosed to marble phyllite and most bedding features were transposed. This is the only Paleozoic unit in the map area with regional metamorphic mineral growth and fabrics. Although the Thompson Gulch thrust fault was not offset across the underlying Railroad Canyon fault, the thrust fault is in a laterally down-ramped position east of the fault compared to its position on the thrust-duplex subdomain on the west side of the fault. Short thrust-fault segments in the southern Stroud subdomain and Goat Mountain domain are kinematically related to the Thompson Gulch thrust fault. These segments transported Mesoproterozoic as well as Paleozoic strata due to lateral-ramp faults, especially in Jakes Canyon.

\section{Baby Joe Gulch Domain}

Along the west-striking range-front segment near the town of Leadore, Idaho, west-striking thrust faults, herein called the Baby Joe Gulch thrust fault system (fig. 3), overlapped the Thompson Gulch domain as well as the subdomains and oblique thrust and lateral ramp faults of the Grizzly Hill domain and the Cabin thrust plate. The lower imbricate contains Kinnikinic Quartzite (Ok) and Saturday Mountain (SOs) and Jefferson Formations (Dj); locally, small slivers of Late Cambrian to Early Ordovician syenite gneiss of the Beaverhead pluton $(\mathrm{O} \mathrm{Gg}$ ) are at the base of the thrust plate. The upper imbricate primarily contains the Late Cambrian to Early Ordovician syenite gneiss of the Beaverhead pluton and the unconformably overlying Middle Ordovician Kinnikinic Quartzite. None of the units in the Baby Joe Gulch domain are in other thrust plates of the central Beaverhead Mountains (except for the Jefferson Formation, which is also in the Maiden Peak spur). They were transported from deeper water settings and match settings of rocks in the Lemhi Range to the west. The rocks in the imbricate faults were folded and broken by high-angle faults, coincident with and in part prior to thrust emplacement.

The Baby Joe Gulch thrust fault system extends to the mouth of Hawley Creek at the southeast corner of the present map, where the basal fault was named "Hawley Creek thrust fault" (Lucchitta, 1966; Skipp, 1985). The semi-continuous thrust-fault segments from west of Jakes Canyon to the mouth of Hawley Creek (and south) confirm that the Baby Joe Gulch thrust fault system along the range front is a more complicated version of the Hawley Creek thrust fault and the overlying Hawley Creek thrust plate. Despite earlier interpretations that the Hawley Creek fault is a major thrust system crossing central Idaho (Skipp, 1987), the Hawley Creek thrust fault is more recently interpreted as an imbricate fault in the footwall of the Poison Creek thrust fault (see Lund and others, 2003b). This fault geometry is based on the apparently much greater offset across the Poison Creek thrust fault (Apple Creek Formation over imbricated footwall Ordovician units, Lund and others, 2003b) than the units across the Hawley Creek fault (Ordovician over Mississippian). The southeasternmost exposed extent of the Poison Creek thrust fault is in the Lemhi Range (fig. 1) and is interpreted to be buried in the Lemhi Valley west of the southern map area. This interpretation remains the best geometric interpretation based on offset on the Poison Creek thrust fault relative to that on the Baby Joe Gulch thrust fault system and the related Hawley Creek thrust fault as well as based on the units involved in footwall imbricate thrust faults in exposures in both ranges.

\section{Thrust-Fault Geometries}

The main thrust faults in the region are northeast vergent and northwest striking (Skipp, 1987; Evans and Green, 2003); these include the thrust faults mapped in the central Beaverhead Mountains. This transport direction resulted in oblique impingement of the thrust faults against generally north-striking basin margins of both Mesoproterozoic and Paleozoic ages, underlain by the Archean-Paleoproterozoic rocks now exposed in the Maiden Peak spur. The northern thrust plates, which were lower in the thrust stack, had relatively more room for northeastward transport than those farther to the south because of the orientation of northeastdirected thrust movement compared to the north-striking edge of the basin margins and basement high. The southern thrust faults in the map area, which were structurally higher in the thrust stack, had a space problem during impingement against the basement high. The space problem is manifested by the structural domains demarcated by compressional structures that are curvilinear in trace and listric in three dimensions. These bounding faults exhibit complex motions: (1) relative sinistral rotations between upper and lower thrust plates along the western transpressional sides of the domains (and subdomains), (2) reverse motion on northern sides, and (3) lateral thrust ramp faults along eastern sides. The steep bounding faults and the lateral-ramp structures are restricted to specific structural domains and (or) subdomains, such that they are closely tied to specific thrust plates and structural levels. In addition to structural interpretations, paleogeographic information gained from comparison of Paleozoic stratigraphic sections among domains is consistent with relative sinistral rotation between structural domains. 
The Baby Joe Gulch thrust fault system, the thrust fault at the southern edge of the Stroud subdomain, the thrust fault on the west flank of the southern Goat Mountain domain, and the Cabin thrust fault are all west striking. These faults overlap and (or) are oblique to many of the lesser structures of the Grizzly Hill domain, the major northwest-striking Cow Creek thrust fault system, and the north-striking thrust faults in the Maiden Peak spur. Thus, the west-striking thrust fault system is a second, younger thrust-fault phase.

Both the Thompson Gulch thrust fault and the Baby Joe Gulch thrust fault system and their associated domains change character over the Railroad Canyon lateral-ramp fault. Whereas the Thompson Gulch thrust fault stepped down over the Railroad Canyon fault, the Baby Joe Gulch thrust fault system was involved in either a horst or anticline over the Railroad Canyon fault. These geometries add to evidence that the Railroad Canyon lateral ramp formed during a thrust fault event that preceded emplacement of the Thompson Gulch thrust fault and Baby Joe Gulch thrust fault system. The eastern extent of the main Baby Joe Gulch thrust fault system was truncated at another steep fault along Cedar Gulch, which originated as another lateral ramp in the Baby Joe Gulch thrust fault system but was reactivated such that its offset was reduced by younger range-front faults.

\section{Cenozoic Extensional Structures}

The sequence of extensional deformation events is revised by the present mapping in comparison to that previously presented by Janecke and others (2001). The most significant change is in interpretations of their "fault set one." Features in "fault set one" are named and considered to be the largest low-angle normal faults of the region (Grizzly Hill, Wildcat, and Phosphoria faults of Janecke and others, 2001; also Divide Creek fault of Janecke and others, 1998, and VanDenburg and others, 1998, renamed Goat Mountain fault by Janecke and others, 2001). However, all are unconformable contacts of Mississippian, Pennsylvanian, or Permian strata deposited on Mesoproterozoic strata. Based on detailed mapping of the stratigraphy and structure, these features are reinterpreted as angular unconformities between tilted Mesoproterozoic strata and disparate overlying Paleozoic sections (this is also a reinterpretation of Lund and others, 2003b). Specifically, the proximity of different stratigraphic successions and different units overlying the unconformity was the result of juxtaposition in thrust plates. In many localities, the unconformable surface displays shearing or brecciation, which probably originated primarily during Cretaceous compressional deformation but also during Tertiary extension.

Many northwest-striking, moderate-angle normal faults cut the Mesoproterozoic strata and bound restricted Eocene Challis Volcanic Group and Eocene to Oligocene depocenters in the northern part of the study area. The largest faults of this type are the west-northwest-striking Lemhi Pass normal fault (Staatz, 1973, 1979; Janecke and others, 2001) and several subparallel faults in the Lemhi Pass thorite district (for example, Bull Moose and Dan Patch faults of Staatz, 1973, 1979). These relatively long, west-northwest-striking, normalfault segments, within and south of the Lemhi Pass district, are generally the oldest of the Cenozoic extensional faults and depocenters. Although, at its southeast end, the Lemhi Pass normal fault is claimed to dip as shallowly as $24-27^{\circ}$ (VanDenburg and others, 1998), its straight map trace suggests its average dip is moderate to steep. These west-northweststriking normal faults tend to parallel older Cretaceous compressional structures, which were reactivated under extension and tend to cause down dropping of the hanging wall of thrust faults and the upper limb of large, thrust-fault-parallel folds. The clearest example is the northwest half of the Lemhi Pass normal fault, where it reactivated the Cow Creek thrust fault.

Thorite-vein deposits of the Lemhi Pass district were previously studied in detail (Staatz, 1972, 1979). However, the wholesale revisions to stratigraphy of Mesoproterozoic rocks and to structures presented in generalized form in Lund and others (2003) and on this map affect interpretations in relation to the Lemhi Pass district. The thorite veins of Lemhi Pass district are restricted to less than $9 \mathrm{~km}(5.6 \mathrm{mi})$ into the hanging wall of the Lemhi Pass normal fault and scattered veins extend $0.8 \mathrm{~km}(0.5 \mathrm{mi})$ into the footwall. Most veins are in the footwall of the Cow Creek thrust fault but a few are in its hanging wall. The deposits are primarily hosted by the Gunsight Formation, above and closely associated with the enigmatic contact between Apple Creek and Gunsight Formations; a few outlier deposits are hosted by rocks of the Apple Creek Formation. These new details suggest post-Cretaceous formation of the veins, corroborating interpretations of Tertiary origins as advocated by Staatz (1979).

Arcuate, east-northeast-striking faults, which are also transverse to the range, controlled deposition and preservation of Eocene Challis Volcanic Group and Oligocene-Miocene sedimentary deposits on the northwest side of the Little Eightmile fault system and south of the Peterson Creek-Black Canyon fault. These east-northeast Cenozoic normal faults reactivated Cretaceous arcuate transpressional faults and were active prior to and coeval with deposition of the Challis Volcanic Group as well as afterwards.

The north-northwest orientation of the Beaverhead Mountains is controlled by north-northwest-striking, active range-front fault segments (Crone and Haller, 1991; Janecke and others, 2001). The range-front faults are orthogonal to the regional extension direction (Stickney and Bartholomew, 1987). Because of that, the main north-northwest-striking segments are interspersed with shorter west-northweststriking, range-front segments where the range-front deviates to nearly west for $10-20 \mathrm{~km}$ stretches. The most significant west-northwest-striking segments in the map area are the prominent segment at the southwest margin of the Goat Mountain domain and the Leadore basin segment (fig. 3). The present mapping, which details stratigraphy and structures in the range itself, suggests that the range-front faults that caused these jogs were controlled by, and reactivated, both the northwest- and the west-striking thrust faults. 
Cenozoic reactivation of steep transpressional faults bounding domains and subdomains also controlled locations and orientations of these short range-front segments.

Both the north-northwest- and west-northwest-striking range-front fault systems are associated with parallel sets of moderate- and low-angle normal faults in footwalls of rangefront faults. Several of the more westerly low-angle normal faults were identified previously and tentatively suggested to have controlled the west-striking jogs in the range front (Janecke and others, 2001). Large, shallow-dipping zones of brecciated Mesoproterozoic rocks are associated with several low-angle normal faults. The largest of these are on Ramsey Mountain, the ridgeline to the north, and the low ridge on the west side of the Lemhi River. Formation of these breccia bodies and nearby belts of breccia associated with Eocene volcanic rocks and basin-fill deposits in Yearian Creek (probable slide blocks) is probably related to the formation of the north-striking, extensional Yearian-Cow-Agency basin and Tendoy basin segment. Observations from the present study suggest that both north- and west-striking low-angle normal faults formed as part of the range-front system. The low-angle faults in the range may have originated either as integral parts of the extension associated with range uplift or as earlier steep normal faults that rotated to shallower dips during subsequent footwall uplift along presently active range-front faults.

A variety of normal faults along the western side of the range reactivated Cretaceous thrust faults and extended the older thrust plates. This is particularly evident for the normal fault that controlled the Leadore basin segment and caused extension in the Baby Joe Gulch domain. This range-front segment is spatially associated with a large number of leadzinc-silver deposits that are restricted to the Baby Joe Gulch domain near the range front. Similar structural remnants of upper Paleozoic units are preserved near the range-front faults all along the southern half of the map area.

In addition to Eocene volcanic rocks, which are widely preserved within fault-bounded basins adjacent to and transecting the range, Eocene granites of the Challis volcanicplutonic complex intruded Mesoproterozoic rocks on the south side of the fault-controlled Little Eightmile basin and along the northwest-striking range-front fault segment between
Little Eightmile fault system and Mollie Gulch. The presence of both the volcanic and plutonic rocks conveys evidence for deep-seated Eocene extension in the Beaverhead Mountains, as part of the extension and magmatism that occurred in much greater volumes across central Idaho. Additionally, the late Eocene and younger basin deposits compose a complex set of unconformity-bounded sequences that, together with the extensional igneous rocks, indicate active Eocene through post-Miocene normal-fault displacements along basinbounding faults. The Miocene to Holocene basin-fill sedimentary deposits are not present near the range crest where local fault-bounded Challis Volcanic Group outcrops are preserved. The absence of Miocene to Holocene deposits in those higher elevation settings indicates active uplift closely followed deposition of the volcanic rocks (after about $45 \mathrm{Ma}$ ).

The Eocene to Miocene deposits are commonly tilted. A number of these dipping packages are interpreted to show Eocene-age extension-related folds, which also deformed preEocene rocks (VanDenburg, 1997; Janecke and others, 1998, 2001). Some folds were directly observed due to continuous exposure, and others are delineated by attitudes that define limbs and hinge, but some of the largest folds are interpreted from opposing attitudes in fault-disrupted or noncontinuous exposures. These extensional folds are commonly orthogonal to and less commonly parallel to bounding normal faults and interpreted as fault-bend type folds (Janecke and others, 1998). In a number of cases, where attitudes in pre-Cenozoic rocks beneath the interpreted fold are available due to discontinuous cover by the younger rocks, evidence for geometrically related folding in pre-Cenozoic rocks is absent (for example, large "Tendoy anticline," of Blankenau, 1999, extending from Ramsay Mountain to Gould Basin, is not corroborated by the present study). The opposing attitudes in Cenozoic rocks in these cases are better explained as localized preservation of tilted sections and (or) perhaps as original deposition in different sub-basins. A number of cross sections, drawn across these interpreted Cenozoic folds, display significant changes in stratigraphic units, both in thickness and in unit preservation, that also do not support folds in the Cenozoic rocks. In those cases, attitudes more clearly represent syndepositional rotations along faults. 


\section{DESCRIPTION OF MAP UNITS}

\section{SURFICIAL DEPOSITS}

Qa Alluvium (Holocene) - Composite unit of unconsolidated cobble, gravel, sand, silt, and clay. Formed as alluvial deposits in valleys of active streams and in alluvial fans. Includes reworked moraine and outwash deposits. Thickness variable, generally less than $5 \mathrm{~m}$ (16 feet [ft]) thick

Qls

Landslide deposits (Holocene and Pleistocene) - Debris from landslides. Most common in areas underlain by Eocene volcanic rocks (Tc) and Eocene to Miocene sedimentary deposits (Tsl, Tsu, and Tm). Thickness variable, some deposits as much as $20 \mathrm{~m}(66 \mathrm{ft})$ thick

Glacial deposits (Holocene and Pleistocene) - Unconsolidated boulder, cobble, and sand deposits in glacial moraines and in extensive glacial outwash deposits. Locally includes glacial deposits reworked by active streams. Thickness variable, generally 5-20 m (16-66 ft) thick

Qt

Terrace deposits (Holocene and Pleistocene) - Unconsolidated deposits perched in terraces above modern streams and forming ridge-capping gravels. Unconsolidated boulder to pebble conglomerate interbedded with sand and mud. Accumulated as stream, alluvial fan, and colluvial debris. Locally includes lesser landslide and glacial outwash deposits. Thickness variable, generally less than $20 \mathrm{~m}(66 \mathrm{ft})$ thick

\section{CENOZOIC SEDIMENTARY ROCKS}

$\mathrm{Tm}$

Mudstone deposits (middle Miocene) - Thin- to thick-bedded, brownish mudstone, siltstone, and sandstone containing thin pebble-conglomerate lenses (M'Gonigle, 1994; VanDenburg, 1997). Contains beds with distinctive horse, camel, and rhinoceros fossil assemblages (M'Gonigle, 1994). Dated at about 16-12 Ma $\left({ }^{40} \mathrm{Ar} /{ }^{39} \mathrm{Ar}\right.$ dating, VanDenburg and others, 1998). Preserved near Bannock Pass in southern Horse Prairie basin, a feature that extends across the Montana-Idaho border. Named "mudstone unit" by M'Gonigle (1994) and referred to as "sedimentary rocks of Bannock Pass" by VanDenburg and others (1998). Commonly overlain by ridge-capping gravels (Qt). Angular unconformity at base, above the older basin-fill units (Tsu, Tsl, and Tc). Probably age-equivalent to strata along west side of central Beaverhead Mountains south of Yearian Creek. As much as $230 \mathrm{~m}(755 \mathrm{ft})$ thick but poorly exposed

Basin-fill deposits, upper (lower Miocene to Oligocene) - Basin-fill deposits exhibiting distinctly diverse characteristics dependent on structural setting. Unit present in Horse Prairie basin on east side of central Beaverhead Mountains. Named "sedimentary rocks of Everson Creek" and correlated with units on west side of Horse Prairie basin by VanDenburg and others (1998).

In Horse Prairie basin, unit consists of interbedded shale, siltstone, sandstone, and metasandstone- and siltite-pebble conglomerate. Conglomerate localized in paleovalleys. Local thin lacustrine limestone lenses (VanDenburg, 1997). Sediments are locally tuffaceous. Angular unconformities at top and base of unit.

Along west side of the Beaverhead Mountains between Sandy and Kenney Creeks, unit is coarser than equivalent rocks on east side of central Beaverhead Mountains. Unit composed of cobble to boulder conglomerates (Blankenau, 1999). Deposited in active range-front-fault environment.

During deposition, Horse Prairie basin was relatively quiescent, and these deposits exhibit less influence of syndepositional faulting than age-equivalent deposit on western flank of range. As much as 2,000 m (6,562 ft) thick in Horse Prairie basin (M'Gonigle, 1994; VanDenburg, 1997)

Tsl Basin-fill deposits, lower (Oligocene to upper Eocene) - Composite unit of sandstone, conglomerate, limestone, and shale. Boulders (less than about $0.5 \mathrm{~m}$ in diameter), cobbles, and pebbles in conglomerate mainly from Mesoproterozoic metasedimentary rocks of the locally exposed Apple Creek (Yac), Gunsight (Yg), and Swauger (Ys) Formations; deposits in upper Pattee Creek and Gould Basin contain cobbles to 
boulders of Mesoproterozoic granite (as much as $2 \mathrm{~m}$ in diameter). Most conglomeratic deposits contain minor volcanic clasts; some sandstones and shales are tuffaceous.

Limestones are fine grained to aphanitic, generally laminated, and platy. Small gastropod fossils are common (Flores and M'Gonigle, 1991). Formed in freshwater lakes and hot springs.

Top and base of unit are angular unconformities. Within the section, angular unconformities and lenticular layers are also common (Lucchitta, 1966; VanDenburg and others, 1998). These are the "Medicine Lodge beds" of Scholten and others (1955) and M'Gonigle and Hait (1997) and also called "sediments of Bear Creek" by VanDenburg and others (1998).

Deposited during early phases of extensional faulting that led to local structurally controlled paleovalleys and to present basin-and-range topography (VanDenburg and others, 1998; Janecke and others, 2000). The very large boulders of Mesoproterozoic augen gneiss in upper Pattee Creek and Gould Basin were interpreted as evidence of major river drainages in which the boulders traveled about $65 \mathrm{~km}$ from locations where Mesoproterozoic granite is presently exposed (Janecke and others, 2000). However, the present mapping determined that the Cow Creek thrust fault is concealed beneath the Gould Basin boulder occurrence and, because this fault carries the granite (Lund and others, 2003a, b), it is possible that granite is also in the buried upper thrust plate. Thus, there may have been a more proximal source for the granite boulders prior to development of the present Gould Basin topography. As thick as 1,900 m (6,234 ft) (M'Gonigle and Hait, 1997; VanDenburg and others, 1998)

\section{EOCENE CHALLIS VOLCANIC-PLUTONIC COMPLEX}

\section{CHALLIS VOLCANIC GROUP}

Challis Volcanic Group, undivided (Eocene) - Composite acidic- to intermediate-composition tuff and flow units of the Challis Volcanic Group. Regionally, extrusive units mostly erupted about 51-45 Ma, although minor activity persisted to about $39 \mathrm{Ma}$ (Fisher and others, 1992; Fisher and Johnson, 1995). There are four informal members in the map area, which are not mapped separately in this study.

The youngest part of the volcanic succession is tannish to greenish, quartz-sanidine welded tuffs with interlayered dark dacite lava flows and conglomerate. These overlie the regionally recognized greenish-white, crystal-vitric, biotite-bearing, "rhyolite tuff of Curtis Ranch" of Staatz (1979: VanDenburg, 1997; Blankenau, 1999), in which crystal fragments are predominantly quartz and plagioclase. Some exposures of the rhyolite tuff of Curtis Ranch contain abundant volcanic lithic fragments and upper part contains flow-breccia layers. Tuffs throughout upper part of the volcanic succession are compacted and locally welded. Upper part of the volcanic succession is as much as $400 \mathrm{~m}(1,312 \mathrm{ft})$ thick where most completely preserved.

The middle part of the volcanic succession consists of thick andesitic, basaltic, and rhyodacitic flow and flow-breccia units with several thin interlayered rhyolite tuffs (Staatz, 1979; VanDenburg, 1997; Blankenau, 1999). The most widespread unit in the middle part of the volcanic section contains dark olive-green, to gray, to reddish-brown, aphanitic to fine-grained, compound basalt to rhyodacite flows. These flows are commonly porphyryitic. Augite phenocrysts are common and biotite phenocrysts are also present. Matrix contains mostly plagioclase but potassium feldspar is in some flows and some flow units have relatively high potassium contents (Staatz, 1979). Flows have basal flow breccias and vesicular-textured tops. These basalt-rhyodacite flows are the most widespread volcanic rocks in the map area. These middle-unit flows form the base of the Challis Volcanic Group in the fault block south of the Lemhi Pass normal fault. The thin rhyolites interlayered in the middle unit are composed of light-colored, crystal, vitric, or lithic tuffs. Middle unit is as much as $1,100 \mathrm{~m}(3,608 \mathrm{ft})$ thick. 
The oldest part of the volcanic succession is composed of interlayered tuff and conglomerate units, including basal conglomerate. Greenish-white, unwelded rhyolite vitric tuff (vitric tuff of Lemhi Pass in Staatz, 1979) locally forms the top of the basal part of the volcanic succession in the study area. This vitric tuff bears minor tuffaceous and crystal fragments and is as much as $125 \mathrm{~m}$ (410 ft) thick. The bulk of the basal unit is light pinkish-gray, poorly welded to unwelded rhyolite tuff. The distinctive feature of the basal tuff is abundant lithic fragments, especially clasts of the fine-grained metasandstone and siltite country-rock, but also vitric, crystal, and tuffaceous clasts. The fragments are generally less than 1 centimeter $(\mathrm{cm})$ in diameter and subangular to subrounded. Conglomerate, predominantly bearing metasedimentary country-rock pebbles to cobbles is locally interbedded between the two rhyolitic units ("conglomerate of Flume Creek" in Staatz, 1979). Basal unit of the volcanic succession is as much as 500-650 m thick.

Coarse conglomerate is locally preserved at or near base of Challis Volcanic Group, where base is best exposed in narrow, early tilt blocks that cross the northern part of the map area. Subrounded to rounded clasts are pebbles to cobbles of Mesoproterozoic quartzite, fine-grained feldspathic metasandstone, and fine-grained micaceous siltite. Cobbles are derived from rocks that underlie the Eocene volcanic rocks. Sandy matrix is locally tuffaceous and moderately lithified. Basal conglomerate is in wedgeshaped deposits that are as much as $45 \mathrm{~m}$ (148 ft) thick.

Challis Volcanic Group is preserved as thick deposits in the fault-bounded valleys on both sides of the range, although not widely exposed there. Best exposures within the tilted fault block of the range were preserved in local early fault basins. General stratigraphic sections are described from exposures in the following localities: the Lemhi basin on the west side of the range (Blankenau, 1999), the Horse Prairie basin east of the range (M'Gonigle, 1994; M'Gonigle and Hait, 1997; VanDenburg, 1997), and the Kenney Creek-Lemhi Pass basin that straddles the range (Staatz, 1979; Blankenau, 1999). There is considerable apparent stratigraphic diversity among those isolated exposures, but the three general units of the volcanic succession are recognized in each basin. The stratigraphic succession of the Beaverhead Mountains generally matches the more complete succession described in the Lemhi Range about $24 \mathrm{~km}(15 \mathrm{mi})$ southwest of the map area where middle potassium-rich andesite-dacite-basalt flows are underlain by massive rhyolitic tuffs and overlain by a variety of thinner welded ash-fall-tuff units (Tysdal and Moye, 1996). Both Lemhi Range (proximal) and Beaverhead Mountains (distal) volcanic rocks were probably outflow deposits from one of the calderas of the Van Horn Peak cauldron complex (Tysdal and Moye, 1996), the eastern margin of which lies about $70 \mathrm{~km}$ (43 mi) west of the Beaverhead Mountains.

Stratigraphic variations between exposures of volcanic rocks in the map area resulted from differential erosion and different distances from sources. The variation may also have resulted from deposition in middle Eocene fault-controlled paleovalleys, including in the Kenney Creek-Lemhi Pass basin (Janecke and others, 2000). Additionally, the local, interbedded, conglomeratic wedges indicate synvolcanic faulting that also caused disrupted landscapes and local differences in time of basin formation

\section{INTRUSIVE ROCKS}

Rhyolite dike (Eocene) - Medium-gray, aphanitic matrix, fine-grained, feldspar-phenocrystic rhyolite dikes

Granite (Eocene) - Light gray, hornblende-biotite granite and porphyritic granite. Also, finegrained, hornblende-biotite granodiorite in margin of granite south of Little Eightmile Creek and in other small exposures. Intruded into reactivated, steep, transpressional parts of fault zones and ductilely deformed rocks along and near Little Eightmile Creek. The largest exposure, south of the mouth of Little Eightmile Creek, is surrounded by an about $200-\mathrm{m}$ (656 ft)-wide contact metamorphic hornfels zone in the Apple Creek Formation

Mafic dike (Eocene) - Black to dark-gray, fine-grained, mafic intrusive rock in thin dikes. Reported compositions include diorite and basalt. Commonly near the faulted contact between Apple Creek and Gunsight Formations and in fold hinges and fracture zones (for example, Copper Queen mine area). Also, several small bodies in exposures of Challis Volcanic Group 


\section{MESOZOIC TO NEOPROTEROZOIC? SEDIMENTARY AND METASEDIMENTARY ROCKS}

$\mathrm{kd}$

$\mathrm{Pp}$

PMs

$\mathrm{Mb}$
Dinwoody Formation (Lower Triassic) - Yellow-tan, fissile, silty shale and interbedded yellowish-weathering, dark-gray limestone. Poorly exposed. Base unconformable. About $300 \mathrm{~m}(984 \mathrm{ft})$ thick

Phosphoria Formation (Permian) - Black chert, gray carbonate rocks, and bluish siltstone preserved in the southern range crest in the map area. Upper part of preserved Phosphoria Formation is bedded black chert with thin beds of dolostone and limestone. Chert beds exhibit characteristic bluish-white phosphatic spots on surface. Chert is about $50 \mathrm{~m}$ (164 ft) thick and equivalent to "Tosi Chert Member" of McKelvey and others (1959). Lower part of formation is dark-gray dolostone and minor limestone containing dark-gray-to-black, ropy chert nodules, mapped as "Phosphoria and Park City Formations, undivided" by Lucchitta (1966). About $280 \mathrm{~m}$ (919 ft) thick. Lowest exposed beds are bluish siltstone with millimeter-scale, orange-weathering fragments. Lowest beds less than $30 \mathrm{~m}(98 \mathrm{ft})$ thick.

These rocks were deposited in the western extent of the Phosphoria epicontinental basin (Wardlaw and Collinson, 1986). Lower contact with the Snaky Canyon Formation (PMs) is gradational. Where structural complexity makes it difficult to assign these beds to appropriate formation because lowest beds are not present, some exposures of Phosphoria Formation may be combined with the upper Juniper Gulch Member of the Snaky Canyon Formation. Upper contact is erosional. Locally, unit is unconformably overlain by Lower Triassic Dinwoody Formation ( $\mathrm{kd})$ or Challis Volcanic Group (Tc).

Rocks of the Phosphoria epicontinental basin have potential for phosphate resources as well as byproduct uranium (U), fluorine (F), cadmium (Cd), chromium (Cr), nickel (Ni), molybdenum (Mo), silver (Ag), rare earth elements (REE), and black-shale vanadium (V) resources (Oberlindacher and Hovland, 1979). Base of the unit is exposed in many bulldozer-cut prospects made during past uranium exploration. Phosphate in the Phosphoria Formation forms pelletal phosphorite interbedded with organic-matter-enriched mudstone and siltstone, limestone, dolomite, and chert. Potential economic interest is restricted to shales in the Phosphoria Formation, as described by Oberlindacher and Hovland (1979). Total thickness is about $260 \mathrm{~m}$ (853 ft) (Lucchitta, 1966)

Snaky Canyon Formation, undivided (Lower Permian to Upper Mississippian) - Upper and lower carbonate members and a middle sandstone member comprise the Snaky Canyon Formation. The Juniper Gulch Member, upper member of the Snaky Canyon, is medium-bluish-gray, sandy dolostone with interbedded quartz sandstone layers. Amount of interbedded sandstone decreases upward, grading to predominantly light- to medium-gray, cherty dolostone. The underlying Gallagher Peak Sandstone Member, the middle member, is similar to the older Upper Mississippian Bluebird Mountain Formation (Mb) but with larger proportion of calcareous cement. The basal Bloom Member is medium- to dark-gray, cherty limestone with common chert nodules and interbedded thin quartz sandstone similar to sandstone of Bluebird Mountain Formation.

Lower contact is abrupt, at base of lowest carbonate beds; upper contact is gradational.

Different facies in thrust duplex and Rocky Canyon subdomains of southeastern part of map. Rocks in the Rocky Canyon subdomain contain more sandstone and quartzite, in comparison to rocks in the thrust duplex subdomain. They may be more properly mapped as the Quadrant Formation, as used by Lucchitta (1966), now considered an eastern, cratonal equivalent facies (Skipp and others, 1979a).

Type section for formation is in southern Beaverhead Mountains, where total thickness is $1,350 \mathrm{~m}(4,429 \mathrm{ft}$ ) (Skipp and others, 1979a). In the study area, the Snaky Canyon Formation totals about $560 \mathrm{~m}$ (1,837 ft) thick (reinterpreted from Lucchitta, 1966)

Bluebird Mountain Formation (Upper Mississippian) - Light-brown weathering, very fine grained, light-gray, quartzitic sandstone and lesser quartzite, calcareous sandstone, and sandy limestone. Unfossiliferous. Lower contact is gradational, at base of first 
$\mathrm{Mr}$

Ms

$\mathrm{Mm}$

Dj

carbonate-cemented quartz sandstone; upper contact is abrupt. Quartz sands derived from inner craton (Skipp and others, 1979a). Only recognized in small area on west side of Railroad Canyon, directly overlying type section of the Railroad Canyon For-

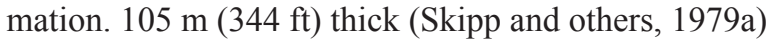

Railroad Canyon Formation (Upper Mississippian)—Pink-, yellow-, orange-weathering, dark-gray shale, mudstone, silty limestone, and calcareous siltstone. Strata are thin bedded to fissile and flaggy. Dark shale and siltstone have a musty odor. Lower and upper contacts are conformable and relatively abrupt. Unit is poorly exposed and the surface expression is as swales and valleys, in which springs and slumps are preferentially located. Basal strata are siltstone and mudstone of shallow-water origin, overlain by deep-subtidal shale and by cycles of deep- to intermediate-subtidal calcareous siltstones (Batt and others, 2007).

Formation mapped previously as Big Snowy Group (Lucchitta, 1966) and Big Snowy Formation (Skipp, 1984). Unit occupies a narrow facies belt formed in an intraramp basin known from the Beaverhead Mountains study area (Skipp and others, 1979b; Batt and others, 2008). Considered facies equivalent to the South Creek, Surrett Canyon, and Arco Hills Formations of the foredeep carbonate bank sequence of Idaho and the Big Snowy Formation of the cratonal section of Montana (Skipp and others, 1979b; Wardlaw and Pecora, 1985).

Shale in unit commonly acts as locus for faults that in many places excise all or part of formation. Slivers of Railroad Canyon Formation are preferentially silicified along fault zones; narrow zones of silicified siltstone are common indicators of faults

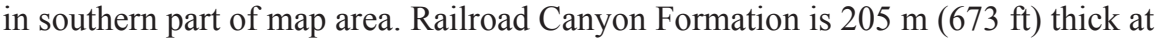
type section on west side of upper Railroad Canyon (Wardlaw and Pecora, 1985)

Scott Peak Formation (Middle Mississippian) - Medium-gray, medium- to thick-bedded, mostly pure limestone. Much of unit contains orange-weathering, wispy and bedded, dark-gray chert. Beds are fossiliferous, with corals and brachiopods predominant; encrinite layers are common but not diagnostic. Thin-bedded strata were described in the upper part by Lucchitta (1966). Typically forms cliffy exposures. Intensely cleaved as the result of deformation associated with thrust faulting. Brecciated and recemented by calcite near low-angle normal faults. Previously mapped as Madison Limestone following cratonal basin terminology (Lucchitta, 1966) prior to more recent facies interpretations that the unit in the central Beaverhead Mountains was deposited in a miogeoclinal setting (Skipp and others, 1979b). Although commonly thinned by low-angle normal faults, unit may be as much as $700 \mathrm{~m}$ (2,296 ft) thick (Skipp and others, 1984)

Middle Canyon Formation (Middle and Lower Mississippian) - Silty limestone with shale partings and thinly interbedded shales. Limestones are in thin to medium beds that originated as carbonate mudstone (Skipp and others, 1979b). Base is exposed on the south side of Goat Mountain and, there, determined to be an erosional unconformity. Unit formed in lower portions of prograding carbonate-bank complex (Huh, 1967). Also preserved in Thompson Gulch domain where unit was transformed into thinly laminated, fine-grained, dark-gray phyllitic marble and calcareous phyllite. Previously mapped as Lodgepole Formation following cratonal basin terminology (Lucchitta, 1966) but herein included in shelf (miogeoclinal) succession (Skipp and others, 1979b). About $250 \mathrm{~m}$ (820 ft) thick but complicated by isoclinal folding and thrust faulting

Jefferson Formation (Upper Devonian) - Primarily dark-gray dolostone with lesser amounts of limestone, limestone evaporite-solution breccia, and sandy dolostone. Tectonic brecciation of unit in most locations makes identification of bedding difficult. Base of unit is in angular unconformity with underlying Mesoproterozoic, Ordovician, and Silurian rocks. Ruppel and Lopez (1988) reported a maximum thickness of about $825 \mathrm{~m}(2,707 \mathrm{ft})$ in Lemhi Range to the west where formation includes Middle and Upper Devonian members older than rocks deposited in this map area; unit abruptly thins from Lemhi Range toward Beaverhead Mountains but thickens eastward into southwestern Montana (Sloss, 1954; Scholten, 1957; Scholten and Hait, 1962; Grader and Dehler, 1998). Jefferson Formation in Lemhi Range and Beaverhead Mountains 
was deposited in miogeoclinal setting but was deposited in the cratonal basin east of the study area. Preserved in lower thrust slivers of Baby Joe Gulch thrust fault system along western range front. About $60 \mathrm{~m}(197 \mathrm{ft})$ thick in study area where only upper part of formation is present. is medium-dark-gray to medium-gray, finely crystalline dolostone that weathers to distinctly mottled lighter gray colors. Black chert nodules are also common as well as numerous beds with abundant fossils and fossil fragments. This grades downward into yellowish-gray to medium-gray, finely crystalline dolostone characterized by a network of irregular, interlaced, hairlike wisps and veinlets of white dolostone and locally by abundant black chert nodules. Most exposures in Beaverhead Mountains are the yellowish-gray lower dolostone. Subdivided into several members to the west in the Lemhi Range (Ruppel and Lopez, 1988). The two rock types that are in the Beaverhead Mountains are probably equivalent to lower part of formation as mapped in the Lemhi Range. Top of formation is an erosional unconformity. About $20 \mathrm{~m}(66 \mathrm{ft})$ thick um-grained, vitreous orthoquartzite. Unit is compositionally supermature and well sorted. Subrounded quartz grains are tightly cemented and, in many cases, are difficult to distinguish from the quartz cement. Where lower contact is not structural, unit rests unconformably on Upper Cambrian-Lower Ordovician syenogranite $(\mathrm{O} € \mathrm{~g})$. Although determined to have been deposited on the Beaverhead pluton in the restricted exposures of the present map area, detrital zircon analyses do not indicate grains of Late Cambrian age either in the Beaverhead Mountains (one sample from Italian Gulch in present study area) or regionally (Baar, 2009). Deposited in foreshore to shoreface environments (James and Oaks, 1977). Preserved only in Baby Joe Gulch domain along western range margin. As much as $30 \mathrm{~m}$ (98 ft) thick

O€d Dolostone (Middle Ordovician? to Upper Cambrian?)-Fine-grained, greenish-gray, fossiliferous dolostone and dolomitic limestone. Thin, light-orange wisps common. Distinctive 1- to $2-\mathrm{cm}(<1$ inch [in]) rip-up clasts, indicating possible tidal reworking of mud-cracked deposits. Unit preserved between underlying quartzite-pebble conglomerate (€Zc) or quartzite of Mesoproterozoic Swauger Formation (Ys) and overlying Upper Mississippian to Lower Permian Snaky Canyon Formation (PMs). Both upper and lower contacts are unconformable. Locally exposed in far eastern extent of Grizzly Hill domain, in bulldozer cuts in upper Hood Gulch and about $1 \mathrm{~km}(0.6 \mathrm{mi})$ east of there. These rocks are unlike other carbonate units to the west; they are most similar to thin Middle Cambrian shale and carbonate adjacent to the eastern edge of the map where they were probably included in Summerhouse Formation by M'Gonigle (1994). May represent a remnant of the western edge of cratonal-shelf sedimentary rocks, possibly equivalent to the Middle Cambrian Meagher Limestone in southwest Montana. About $15 \mathrm{~m}(50 \mathrm{ft})$ thickness preserved to -cobble conglomerate and quartzite. Most recognized exposures are quartzite with interbedded conglomerate. Where conglomerate is lacking, unit is difficult to distinguish from and probably included with underlying Swauger Formation (Ys). Quartzite contains bimodal grain-size distribution and is cemented by silica in lower part of unit. Conglomerate layers are as thick as $2 \mathrm{~m}(6.6 \mathrm{ft})$; cobbles derived primarily from subjacent quartzite of the Mesoproterozoic Swauger (Ys) and Gunsight (Yg) Formations; minor clasts of vein quartz and rare chips of light-colored siltite. Amount of carbonate cement increases upward. Base of formation is angular unconformity over Apple Creek, Gunsight, and Swauger Formations; top of formation unconformable. Unit may be correlative to Lower Cambrian to Neoproterozoic Wilbert Formation. Maximum thickness about $20 \mathrm{~m}(66 \mathrm{ft})$

Flathead Quartzite (Middle Cambrian) - Light gray quartz sandstone to quartzite. Quartz grains rounded. Some layers contain minor iron-oxide cement, causing reddish-tan weathering. Lower beds are arkosic and contain grit (very coarse sand to fine pebble) layers. Upper beds bear scolithos tubes. Base deposited unconformably on Paleop- 
roterozoic gneiss $(\mathrm{Xg})$. Unit only in Maiden Peak spur at eastern edge of study area where Mesoproterozoic strata are absent and Paleozoic rocks were deposited directly on Paleoproterozoic basement. About $7 \mathrm{~km}(4.3 \mathrm{mi})$ northwest of the northernmost exposure of Flathead Quartzite (along the eastern map margin) upper beds of quartzite are overlain by greenish, micaceous (glauconitic) shales typical of the Middle Cambrian Wolsey Shale. These characteristics led to reinterpretation of the quartzite from Lower Ordovician Summerhouse Formation of the Idaho miogeoclinal succession as interpreted by M'Gonigle (1994) to the Middle Cambrian Flathead Quartzite and Wolsey Shale of the cratonal basin succession. Thickness variable, as much as $70 \mathrm{~m}(230 \mathrm{ft})$ thick

\section{PALEOZOIC INTRUSIVE ROCKS}

O€g Syenogranite (Early Ordovician to Late Cambrian) - Reddish-brown weathering, pink to red syenogranite of Beaverhead pluton and tan-weathering leucosyenite in a small

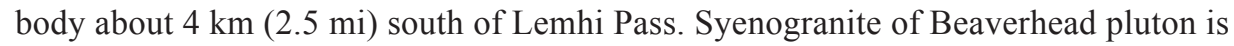
medium to coarse grained, equigranular to subporphyritic. It is composed of quartz, alkali feldspar, biotite, and opaque minerals and bears accessory zircon and apatite. Widespread alteration produced sericite, hematite, leucoxene, limonite, magnetite, chlorite, and quartz. Age of Beaverhead pluton is $488 \pm 5 \mathrm{Ma}$ (sensitive high resolution ion microprobe [SHRIMP] U-Pb zircon dating, Lund and others, 2010). Previously, relations from exposures about $20 \mathrm{~km}(12 \mathrm{mi})$ south of the present study area were interpreted as intrusive contacts between the Beaverhead pluton and the Middle Ordovician Kinnikinic Quartzite (Scholten and Ramspott, 1968; Skipp, 1984).

However, based on dates obtained from the Beaverhead pluton, the contact must be depositional because the pluton is significantly older than the Middle Ordovician Kinnikinic Quartzite (Lund and others, 2010). Thus, this pluton was exhumed by the Middle Ordovician, before deposition of the Kinnikinic Quartzite (Lund and others, 2010).

The Beaverhead pluton is preserved in Baby Joe Gulch thrust fault system (Hawley Creek thrust sheet as shown by Lucchitta, 1966), a lower imbricate thrust sliver related to the Poison Creek thrust fault (Lund and others, 2003b) at low elevations on the western flank of the range in the southern part of the map.

Leucosyenite of Lemhi Pass is fine- to medium-grained, buff-colored alkali-feldspar syenite. It consists of microcline, albite microperthite, cryptoperthite, quartz, and lesser biotite, opaque minerals, zircon, and apatite. The leucosyenite crops out in an area about $250 \mathrm{~m}$ long and about $75 \mathrm{~m}(820 \times 246 \mathrm{ft})$ wide. It intruded Mesoproterozoic Gunsight Formation. Age of the Lemhi Pass syenite stock is about $530 \mathrm{Ma}$ (unpublished SHRIMP U-Pb date, Gillerman and others, 2008)

\section{MESOPROTEROZOIC METASEDIMENTARY ROCKS}

Swauger Formation (Mesoproterozoic) - Tan-weathering, light-gray, medium- to coarsegrained quartzite. Quartz content typically ranges from 90 to 95 percent in well-rounded, well-sorted, glassy grains. Quartz grains are quartz cemented but detrital quartz grains remain distinguishable. Feldspar content seldom exceeds 5-10 percent. Beds are 0.5-2 m (1.6-6.6 ft) thick and commonly display trough cross laminations and lesser herringbone cross laminae. Two-dimensional ripples and subaqueous dunes are common in unit (Tysdal, 2000b). Some beds capped by thin $(<0.5 \mathrm{~cm} \mathrm{[<0.2} \mathrm{in]),} \mathrm{reddish-tan}$ or greenish-tan siltite or argillite layers. Deposited in a tidal environment based on compositional maturity of quartzites, presence of herringbone crossbeds, subordinate current-cap deposits on some dunes, rare antidunes, and local flaser and lenticular bedding (Tysdal, 2000b). Base gradational; top eroded. Regional thickness as much as $3,100 \mathrm{~m}(10,171 \mathrm{ft})$, but only about $500 \mathrm{~m}(1,640 \mathrm{ft})$ are exposed in the map area 


\section{LEMHI GROUP}

Yg Gunsight Formation (Mesoproterozoic) - Light- to dark-gray, very fine to medium grained, arkosic metasandstone; about 35 percent feldspar, 50 percent quartz, and as much as 15 percent metamorphic micas. Bed thicknesses from 5 to $100 \mathrm{~cm}$ (2-39 in). Most common sedimentary features are parallel laminations, including common heavy-mineral lamination. Decimeter-thick trough and planar crossbeds are typical; hummocky cross-stratification locally. Mud chips locally. Unit contains finer grained sand and relatively more biotite on west side of range (Cow Creek thrust plate) and is lighter colored, containing less biotite but more distinct heavy-mineral lamination in eastern exposures. Strata in the footwall to the Cow Creek thrust fault (Lemhi Pass and Pattee Creek domains) contain two generations of metamorphic muscovite (early oriented and younger random).

Deposited in fluvial environment (Tysdal, 2003). Sediment derived in part from Archean and Paleoproterozoic basement on eastern edge of map (Tysdal and others, 2005). Through most of area, lower contact is with coarse siltite unit of Apple Creek Formation (Yac) and contact is commonly angular but also contains quartz veins and local tectonic fabrics, suggesting it is a sheared unconformity. In Cabin thrust plate, lower contact is sheared and brecciated but interpreted to be an unconformable depositional contact above Paleoproterozoic gneiss (Tysdal and others, 2005) rather than a fault (contact is labeled "fault D" by M'Gonigle, 1994). Unit grades upward into Swauger Formation (Ys). Total unit thickness regionally is 4,000 m (13,123 ft; (Tysdal, 2003) but

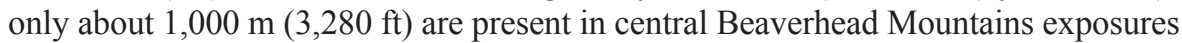
grade and structural position; light- to medium-grayish-green in lowest metamorphic-grade exposures mostly extending from range crest to Montana side of range and light to dark gray to west on Idaho side of range. Weathers dark rusty-gray to dark maroon-gray. Contains 40-60 percent quartz, 25-30 percent potassium feldspar, 5-15 percent plagioclase, about 3 percent clay matrix, and minor fine-grained, metamorphic chlorite, biotite, and (or) muscovite localized near ductile structures. Much of unit is massive, coarse siltite containing rare magnetite-bearing, heavy-mineral layers. Other common bedding type is parallel lamination, most commonly displaying erosional bases and grading upward from fine-grained, light-green or light-gray metasandstone to medium-grained darker greenish or gray siltite. Graded beds range from 1 to $100 \mathrm{~cm}$ thick (0.4-39 in); most about 10-25 cm (3.9-9.8 in) thick. Other sedimentary structures common in the laminated and graded beds include intrabasinal mud-chip clasts in the graded-bedding layers and more rarely climbing ripples, convolute lamination, and dish structures.

Rocks metamorphosed to greenschist facies, mostly containing sparse finegrained chlorite, muscovite, or biotite. Chlorite, where present, is generally randomly oriented. In contrast, biotite and (or) muscovite formed phyllitic fabrics in ductile deformation zones - generally either along fold hinges or near thrust faults. Additionally, second generations of fine- to medium-grained muscovite formed in secondary cleavage fabrics in the most deformed rocks.

In Lemhi Pass and Pattee Creek domains (footwall to Cow Creek thrust fault and footwall to Lemhi Pass normal fault), upper contact with Gunsight Formation (Yg) is characterized by angular bedding relations - several locations demonstrate overturned Apple Creek Formation (Yac) below upright Gunsight Formation (Yg). In these areas, the contact zone is quartz veined and characterized by phyllitic fabrics. In Cow Creek thrust plate (hanging wall of Cow Creek thrust fault), the contact is more difficult to identify, less tectonized, and possibly gradational. Regionally, the contact is not overtly angular, but upper contact may have been truncated by erosion before deposition of Gunsight Formation (Tysdal and others, 2005). In the map area, the contact may represent an important angular unconformity as well as a zone of structural decoupling of undetermined origin.

Apple Creek Formation is defined following studies of Tysdal (2000a, b). These rocks formed as below-wave-base deposits, primarily as turbidite deposits with minor 
debris flows (Tysdal, 2000b). In this central Beaverhead Mountains map area, coarse siltite unit of Apple Creek Formation is uniformly thicker and coarser than described for Lemhi Range, directly to the west (Tysdal, 2000b). Paleoproterozoic basement rocks on the east side of the Beaverhead Mountains were a significant source terrain as described for the Gunsight Formation (Tysdal and others, 2005). Total thickness exposed in map area about 2,000-2,500 $\mathrm{m}(6,560-8,200 \mathrm{ft})$. Base not exposed

\section{PALEOPROTEROZOIC INTRUSIVE ROCKS}

Xg Orthogneiss (Paleoproterozoic) — Reddish-orange-weathering, light-gray to brown, medium-grained porphyroblastic granite gneiss. Medium-grained groundmass is formed of quartz and subequal amounts of plagioclase, potassium feldspar, and combined hornblende and biotite (M'Gonigle, 1994). Porphyroblasts are coarse-grained microcline that originally were phenocrysts. Exhibits pervasive planar fabric and poorly formed compositional layering defined by oriented mafic minerals, elongated porphyroblasts, and groundmass quartz and feldspar. Some local mafic masses occur in the gneiss, as do crosscutting quartz veins and pegmatite dikes. Paleoproterozoic emplacement age is about $2.46 \mathrm{Ga}$ (thermal ionization mass spectrometer [TIMS] U-Pb zircon, Kellogg and others, 2003)

\section{References Cited}

Aleinikoff, J.N., Slack, J.F., Lund, K., Evans, K.V., Fanning, C.M., Mazdab, F.K., Wooden, J.L., and Pillers, R.M., 2012, Constraints on the timing of $\mathrm{Co}-\mathrm{Cu} \pm \mathrm{Au}$ mineralization in the Blackbird district, Idaho, using SHRIMP U-Pb ages of monazite and xenotime plus zircon ages of related Mesoproterozoic orthogneisses and metasedimentary rocks: Economic Geology, v. 107, p. 1143-1175.

Baar, E.E., 2009, Determining the regional-scale detrital zircon provenance of the Middle-Late Ordovician Kinnikinic (Eureka) Quartzite, east-central Idaho, U.S.: Pullman, Washington State University, M.S. thesis, 144 p.

Batt, L.S., Pope, M.C., Isaacson, P.E., Montañez, I., Abplanalp, J., 2007, Upper Mississippian Antler foreland basin carbonate and siliciclastic rocks, east-central Idaho and southwestern Montana, U.S.A.-Distinguishing tectonic and eustatic controls on deposition, in Lukasik, J., and Simo, J.A., eds., Controls on carbonate platforms and reef development: Society for Sedimentary Geology Special Publication 89, p. 147-170.

Beutner, E.C., and Scholten, R., 1967, Probable Cambrian strata in east-central Idaho and their paleotectonic significance: American Association of Petroleum Geologists Bulletin, v. 51, p. 2305-2309.

Blankenau, J.J., 1999, Cenozoic structure and stratigraphy of the southeast Salmon basin, east-central Idaho: Logan, Utah State University, M.S. thesis, 143 p., 3 pl., scale 1:24,000.
Crone, A.J., and Haller, K.M., 1991, Segmentation and the coseismic behavior of Basin and Range normal faultsExamples from east-central Idaho and southwestern Montana, U.S.A.: Journal of Structural Geology, v. 13, p. 151-164.

Evans, K.V., and Green, G.N., compiliers, 2003, Geologic map of the Salmon National Forest and vicinity, east-central Idaho: U.S. Geological Survey Miscellaneous Investigations Map I-2765, 19 p., 2 sheets, scale 1:100,000.

Fisher, F.S., McIntyre, D.H., and Johnson, K.M., compilers, 1992, Geologic map of the Challis $1^{\circ} \times 2^{\circ}$ quadrangle, Idaho, U.S. Geological Survey Miscellaneous Investigations Series Map I-1819.

Fisher, F.S., and Johnson, K.M., eds., 1995, Geology and mineral resource assessment of the Challis $1^{\circ} \times 2^{\circ}$ quadrangle, Idaho: U.S. Geological Survey Professional Paper 1525, 204 p., 23 pl., plus appendixes, scale 1:250,000.

Flores, R.M., and M'Gonigle, J.W., 1991, Oligocene-Miocene lacustrine rudite-dominated alluvial-fan delta, southwest Montana, U.S.A, in Dabrie, C.J., ed., Fan-Delta workshop, Special Issue: Madrid, Spain, Universidad Complutense de Madrid, p. 241-278.

Giles, S.A., and Lund, K., 2018, Digital data for the geologic map of the central Beaverhead Mountains, Lemhi County, Idaho, and Beaverhead County, Montana: U.S. Geological Survey data release, https://doi.org/10.5066/P905PTI4. 
Gillerman, V.S., Fanning, C.M., Link, P.K., Layer, P., and Burmaster, R.F., 2008, Newly discovered intrusives at the Lemhi Pass thorium-REE iron oxide district, IdahoCambrian syenite and mystery ultramafics - Signatures of a buried alkaline complex or two systems?: Geological Society of America Abstracts with Programs, v. 40, no. 1, p. 51.

Grader, G.W., and Dehler, C.M., 1998, Devonian stratigraphy in east-central Idaho-New perspectives from the Lemhi Range and Bayhorse area, in Hughes, S.S., and Thackray, G.D., eds., Guidebook to the geology of eastern Idaho: Pocatello, Idaho Museum of Natural History, p. 29-54.

Hansen, P.M., 1983, Structure and stratigraphy of the Lemhi Pass area, Beaverhead Range, southwest Montana and east-central Idaho: University Park, Pennsylvania State University, M.S. thesis, $112 \mathrm{p}$.

Harrison, S.L., 1985, Sedimentology of Tertiary sedimentary rocks near Salmon, Idaho: Missoula, University of Montana, Ph.D. dissertation, $161 \mathrm{p}$.

Huh, O.K., 1967, The Mississippian system across the Wasatch line, east-central Idaho and extreme southwestern Montana, in Centennial basin of southwest Montana-18th Annual Field Conference, August 9-12, 1967, Guidebook, Billings, Mont., 1967: Billings, Montana Geological Society, p. 31-62.

Isaacson, P.E., Bachtel, S.L., and McFaddan, M.D., 1983, Stratigraphic correlation of the Paleozoic and Mesozoic rocks of Idaho: Idaho Bureau of Mines and Geology Information Circular 37, 4 p.

James, W.C., and Oaks, R.Q., 1977, Petrology of the Kinnikinic Quartzite (Middle Ordovician), east-central Idaho: Journal of Sedimentary Research, v. 47, p. 1491-1511.

Janecke, S.U., Blankenau, J.J., VanDenburg, C.J., and Van Gosen, B.S., 2001, Map of normal faults and extensional folds in the Tendoy Mountains and Beaverhead Range, southwest Montana and eastern Idaho: U.S. Geological Survey Miscellaneous Field Studies MF-2362, scale 1:100,000.

Janecke, S.U., VanDenburg, C.J., Blankenau, J.J., 1998, Geometry, mechanisms and significance of extensional folds from examples in the Rocky Mountain Basin and Range province, U.S.A.: Journal of Structural Geology, v. 20, p. 841-856.

Janecke, S.U., VanDenburg, C.J., Blankenau, J.J., and M'Gonigle, J.W., 2000, Long-distance longitudinal transport of gravel across the Cordilleran thrust belt of Montana and Idaho: Geology, v. 28, p. 439-442.

Kellogg, K.S., Snee, L.W., and Unruh, D.M., 2003, The Mesoproterozoic Beaverhead impact structure and its tectonic setting, Montana-Idaho- ${ }^{40} \mathrm{Ar} /{ }^{39} \mathrm{Ar}$ and $\mathrm{U}-\mathrm{Pb}$ isotopic constraints: Journal of Geology, v. 111, p. 639-652.
Link, P.K., Fanning, C.M., Lund, K., and Aleinikoff, J.N., 2007, Detrital-zircon populations and provenance of Mesoproterozoic strata of east-central Idaho, U.S.A.Correlation with the Belt Supergroup of southwest Montana, in Link, P.K., and Lewis, R.S., eds., Proterozoic Geology of Western North America and Siberia: Society for Sedimentary Geology Special Publication 86, p. 101-128.

Lucchitta, B.K., 1966, Structure of the Hawley Creek area, Idaho-Montana: University Park, Pennsylvania State University, Ph.D. dissertation, 204 p, 1 sheet, scale 1:30,700.

Lund, K., 2008, Geometry of the Neoproterozoic and Paleozoic rift margin of western Laurentia-Implications for mineral deposit settings: Geosphere, v. 4, p. 429-444.

Lund, K., Aleinikoff, J.N., Evans, K.V., du Bray, E.A., DeWitt, E.H., and Unruh, D.M., 2010, SHRIMP U-Pb dating of recurrent Cryogenian and Late Cambrian-Early Ordovician alkalic magmatism in central Idaho-Implications for Rodinian rift tectonics: Geological Society of America Bulletin, v. 122, p. 430-453.

Lund, K., Aleinikoff, J.N., Evans, K.V., and Kunk, M.J, 2004, Proterozoic basins and orogenic belts of central Idaho [abs.]: Geological Society of America Abstracts with Programs, v. 36, p. 271.

Lund, K., Evans, K.V., Doughty, P.T., Chamberlain, K.R., Link, P.K., and Winston, D., 2003a, Geology of the Brushy Gulch fault and its hanging wall and footwall rocks, eastern Idaho: Northwest Geology, v. 32, p. 74-85.

Lund, K.I., Evans, K.V., Tysdal, R.G., and Winkler, G.R., $2003 \mathrm{~b}$, Geologic map of the eastern part of the Salmon National Forest, in Evans, K.V., and Green, G.N., eds., Geologic map of the Salmon National Forest and vicinity, east-central Idaho: U.S. Geological Survey Geologic Investigations Series Map I-2765, sheet 2, scale 1:100,000.

McKelvey, V.E., Williams, J.S., Sheldon, R.P., Cressman, E.R., Cheney, T.M., and Swanson, R.W., 1959, The Phosphoria, Park City, and Shedhorn Formations in the western phosphate field: U.S. Geological Survey Professional Paper 313-A, 47 p.

M'Gonigle, J.W., 1993, Geologic map of the Medicine Lodge Peak quadrangle, Beaverhead County, southwest Montana: U.S. Geological Survey Geologic Quadrangle Map GQ-1724, scale 1:24,000.

M'Gonigle, J.W., 1994, Geologic map of the Deadman Pass quadrangle, Beaverhead County, Montana, and Lemhi County, Idaho: U.S. Geological Survey Geologic Quadrangle Map GQ-1753, scale 1:24,000. 
M'Gonigle, J.W., and Dalrymple, G.B., 1993, ${ }^{40} \mathrm{Ar} /{ }^{39} \mathrm{Ar}$ ages of Challis volcanic rocks and the initiation of Tertiary sedimentary basins in southwestern Montana: Mountain Geologist, v. 30, p. 112-118.

M'Gonigle, J.W., and Hait, Jr., M.H., 1997, Geologic map of the Jeff Davis Peak quadrangle and the eastern part of the Everson Creek Quadrangle, Beaverhead County, southwest Montana: U.S. Geological Survey Geologic Investigations Map I-2604, scale 1:24,000.

M'Gonigle, J.W., Kirschbaum, M.A., and Weaver, J.N., 1991, Geologic map of the Hansen Ranch quadrangle, Beaverhead County, southwest Montana: U.S. Geological Survey Geologic Quadrangle Map GQ-1704, scale 1:24,000.

Mueller, P.A., and Frost, C.D., 2006, The Wyoming Province-A distinctive Archean craton in Laurentian North America: Canadian Journal of Earth Sciences, v. 43, p. 1391-1397.

Oberlindacher, H.P., and Hovland, R.D., 1979, Geology and phosphate resources of the Hawley Creek area, Lemhi County, Idaho: U.S. Geological Survey Open-File Report 79-1283, $18 \mathrm{p}$.

Ruppel, E.T., 1968, Geologic map of the Leadore quadrangle, Lemhi County, Idaho: U.S. Geological Survey Geologic Quadrangle Map GQ-733, scale 1:62,500.

Ruppel, E.T., 1978, Medicine Lodge thrust system, east-central Idaho and southwest Montana: U.S. Geological Survey Professional Paper 1031, 23 p.

Ruppel, E.T., and Lopez, D.A., 1984, The thrust belt in southwest Montana and east-central Idaho: U.S. Geological Survey Professional Paper 1278, 41 p.

Ruppel, E.T., and Lopez, D.A., 1988, Regional geology and mineral deposits in and near the central part of the Lemhi Range, Lemhi County, Idaho: U.S. Geological Survey Professional Paper 1480, $122 \mathrm{p}$.

Ruppel, E.T., O’Neill, J.M., and Lopez, D.A., 1993, Geologic map of the Dillon $1^{\circ} \times 2^{\circ}$ quadrangle, Idaho and Montana: U.S. Geological Survey Miscellaneous Investigations Series Map 1-1803-H, scale 1:250,000.

Scholten, R., 1957, Paleozoic evolution of the geosynclinal margin north of the Snake River Plain, Idaho-Montana: Geological Society of America Bulletin, v. 68, p. 151-170.

Scholten, R., and Hait, M.H., Jr., 1962, Devonian system from shelf edge to geosyncline, southwestern Montana-central Idaho, in Hansen, A.R., and McKeever, J.H., eds., The Devonian system of Montana and adjacent areas, 13th Annual Field Conference Guidebook, Sept. 13-22: Billings, Mont., Billings Geological Society, p. 13-22.
Scholten, R., Keenmon, K.A., and Kupsch, W.O., 1955, Geology of the Lima region, southwestern Montana and adjacent Idaho: Geological Society of America Bulletin, v. 66, p. 345-404, 1 sheet, scale 1:129,000.

Scholten, R., and Ramspott, L.D., 1968, Tectonic mechanisms indicated by structural framework of central Beaverhead Range, Idaho-Montana: Geological Society of America Special Paper 104, 71 p.

Skipp, B., 1984, Geologic map and cross sections of the Italian Peak and Italian Peak Middle Roadless Areas, Beaverhead County, Montana, and Clark and Lemhi Counties, Idaho: U.S. Geological Survey Miscellaneous Field Studies Map MF-1601-B, scale 1:62,500.

Skipp, B., 1985, Contraction and extension faults in the southern Beaverhead Mountains, Idaho and Montana: U.S. Geological Survey Open-File Report 85-545, 170 p.

Skipp, B., 1987, Basement thrust sheets in the Clearwater orogenic zone, central Idaho and western Montana: Geology, v. 15 , p. 220-224.

Skipp, B., Hoggan, R.D., Schleicher, D.L., and Douglass, R.C., 1979a, Upper Paleozoic carbonate bank in east-central Idaho-Snaky Canyon, Bluebird Mountain, and Arco Hills Formations, and their paleotectonic significance: U.S. Geological Survey Bulletin 1486, 78 p.

Skipp, B., Sando, W.J., and Hall, W.E., 1979b, The Mississippian and Pennsylvanian (Carboniferous) Systems in the United States-Idaho: U.S. Geological Survey Professional Paper 1110-AA, p. 1-42.

Skipp, B., Hassemer, J.R., and Detra, D.E., 1984, Geology, geochemistry, and mineral resource potential of the Eighteenmile Wilderness Study Area (ID-43-3), Lemhi County, Idaho: U.S. Geological Survey Open-File Report 84-279, 55 p.

Sloss, L.L., 1954, Lemhi Arch, a mid-Paleozoic positive element in south-central Idaho: Geological Society of America Bulletin, v. 65, p. 365-368.

Staatz, M.H., 1972, Geology and description of the thorium-bearing veins, Lemhi Pass quadrangle, Idaho and Montana: U.S. Geological Survey Bulletin 1351, 94 p., scale 1:24,000.

Staatz, M.H., 1973, Geologic map of the Goat Mountain quadrangle, Lemhi County, Idaho, and Beaverhead County, Montana: U.S. Geological Survey Geologic Quadrangle Map GQ-1097, scale 1:24,000.

Staatz, M.H., 1979, Geology and mineral resources of the Lemhi Pass thorium district, Idaho and Montana: U.S. Geological Survey Professional Paper 1049-A, 90 p. 
Stickney, M.C., and Bartholomew, M.J., 1987, Seismicity and late Quaternary faulting of the northern Basin and Range Province, Montana and Idaho: Bulletin of the Seismological Society of America, v. 77, p. 1602-1625.

Tysdal, R.G., 2000a, Revision of Middle Proterozoic Yellowjacket Formation, central Idaho: U.S. Geological Survey Professional Paper 1601-A, 13 p.

Tysdal, R.G., 2000b, Stratigraphy and sedimentology of Middle Proterozoic rocks in northern part of Lemhi Range, Lemhi County, Idaho: U.S. Geological Survey Professional Paper 1600, $40 \mathrm{p}$.

Tysdal, R.G., 2002, Structural geology of western part of Lemhi Range, east-central Idaho: U.S. Geological Survey Professional Paper 1659, 33 p.

Tysdal, R.G., 2003, Correlation, sedimentology, and structural setting, upper strata of Mesoproterozoic Apple Creek Formation and lower strata of Gunsight Formation, Lemhi Range to Salmon River Mountains, east-central Idaho, chap. A of Tysdal, R.G., Lindsey, D.A., and Taggert, J.E., Jr., Correlation, sedimentology, structural setting, chemical composition, and provenance of selected formations in Mesoproterozoic Lemhi Group, central Idaho: U.S. Geological Survey Professional Paper 1668, p. 1-22.

Tysdal, R.G., Lindsey, D.A., Lund, K.I., and Winkler, G.R., 2005, Alluvial facies, paleocurrents, and source of the Mesoproterozoic Gunsight Formation, east-central Idaho and southwestern Montana, chap. B of O'Neill, J.M., Tysdal, R.G., Lindsey, D.A., Lund, K.I., and Winkler, G.R., 2005, Stratigraphic studies in southwestern Montana and adjacent Idaho - Lower Tertiary Anaconda Conglomerate and Mesoproterozoic Gunsight Formation: U.S. Geological Survey Professional Paper 1700, p. 22-39.
Tysdal, R.G., and Moye, F., 1996, Geologic map of the Allison Creek quadrangle, Lemhi County, Idaho: U.S. Geological Survey Geologic Quadrangle Map GQ-1778, scale $1: 24,000$.

VanDenburg, C.J., 1997, Cenozoic tectonic and paleogeographic evolution of the Horse Prairie half graben, southwest Montana: Logan, Utah State University, M.S. thesis, 152 p., 2 pl., scale 1:24,000.

VanDenburg, C.J., Janecke, S.U., and McIntosh, W.C., 1998, Three-dimensional strain produced by $>50$ m.y. of episodic extension, Horse Prairie basin area, SW Montana, U.S.A.: Journal of Structural Geology, v. 20, p. 1747-1767.

Wardlaw, B.R., and Collinson, J.W., 1986, Paleontology and deposition of the Phosphoria Formation: Contributions to Geology, University of Wyoming, v. 24, p. 107-142.

Wardlaw, B.R., and Pecora, W.C., 1985, New Mississippian-Pennsylvanian stratigraphic units in southwest Montana and adjacent Idaho, chap. B of Sando, W.J., ed., Mississippian and Pennsylvanian stratigraphic units in southwest Montana and adjacent Idaho: U.S. Geological Survey Bulletin 1656, 9 p.
For more information concerning the research in this report, contact the Center Director, USGS Geology, Geophysics, and Geochemistry

Science Center

Box 25046, Mail Stop 973

Denver, CO 80225

(303) 236-1800

Or visit Geology, Geophysics, and Geochemistry Science Center website at https://www.usgs.gov/centers/gggsc 

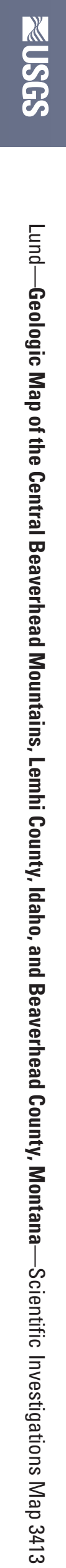